\title{
UNA INTERPRETACIÓN RESTRICTIVA SOBRE LOS EFECTOS DE LA CONSTITUCIÓN EN MORA DEL DEUDOR SEGÚN EL “CÓDIGO CIVIL"
}

[A Restrictive Interpretation of the Effects of Declaring the Debtor in Default According to the "Civil Code"]

\section{Juan Ignacio Contardo GonZÁlez* Universidad Diego Portales, Santiago, Chile}

\begin{abstract}
RESUMEN
El artículo trata de la constitución en mora del deudor según el Código Civil. Frente a la interpretación tradicional que observa la mora del deudor como una lesión del crédito, se postula que la constitución en mora del deudor es sólo un retraso calificado con efectos reducidos principalmente al cobro de intereses moratorios y traslación de riesgos en manos del deudor.
\end{abstract}

\section{Palabras Clave}

Mora del deudor - Retraso -Incumplimiento.

\section{AbStract}

This article analyses the debtor's notice of default in accordance with the Civil Code. In view of the traditional interpretation which considers the debtor's default as credit damage, we hereby propose that declaring the debtor in default is merely aclassified delay with reduced effects, mainly in collection of default interests and transferring risks to the debtor.

\section{KEYWORDS}

Debtor in default - Delay in payment -Breach.

RECIBIDo el 23 de septiembre y ACEPTADo el 20 de diciembre de 2014

* Profesor de derecho civil de la Universidad Diego Portales (Chile). Doctor en derecho por la Universidad de los Andes (Chile).Correo electrónico: juan.contardo@ udp.cl. El presente trabajo forma parte del proyecto FONDECYT de iniciación $\mathrm{N}^{\circ}$ 11130509: "Hacia un sistema de medidas anticipatorias frente al incumplimiento contractual", del cual el autor es investigador responsable. 


\section{INTRODUCCIÓN}

$\mathrm{Al}$ abocarse al estudio de los medios de tutela del acreedor es posible observar que en nuestra doctrina la constitución en mora del deudor ocupa, por lo menos, un lugar privilegiado.

Se observa que en doctrina se ha configurado como un requisito sine qua non del ejercicio de los medios de tutela más importantes ${ }^{1}$ : la indemnización de perjuicios, la pretensión de cumplimiento, la resolución por incumplimiento y la excepción de contrato no cumplido.

Existirían dos razones para llegar a esta conclusión. En primer lugar, la configuración del sistema de remedios se ha efectuado a partir de la indemnización de perjuicios que requeriría siempre la constitución en mora del deudor (artículo 1557 CC.), en especial, respecto de las obligaciones positivas (las negativas no se retrasan por regla general).

$\mathrm{Y}$, en segundo lugar, por la configuración del momento en el que el deudor se constituye en mora. El Código Civil, según parte importante de la doctrina, se ordenó en base a un sistema de constitución en mora automática o ex re: la sola llegada del plazo contractualmente pactado, expreso o tácito, constituiría al deudor en mora (artículo $1551 \mathrm{Ns}^{\circ} 1$ y 2 CC.). Esto traería aparejado que cada vez que el deudor deja de cumplir en tiempo la obligación, se configuraría un incumplimiento suficiente para ejercer cualquiera de los medios de tutela recién descritos. De esta suerte, el retraso se constituye en la práctica como un sinónimo de la mora del deudor para gran parte de los incumplimientos en las obligaciones positivas ${ }^{2}$, dejando a salvo la inejecu-

${ }^{1}$ Para los efectos de la presente investigación utilizaremos como sinónimos las expresiones "medios de tutela del acreedor", "remedios contractuales" (o simplemente "remedios") y "efectos anormales de la obligación". Esta última es la que se ocupa con frecuencia en nuestros manuales y tratados de nuestro medio. La segunda, es la que se ha ocupado como una traducción de la expresión anglosajona remedies, por aquellos autores que abogan por una modernización del derecho de las obligaciones. Frente a la crítica de este neologismo, se ha planteado la necesidad de ocupar una nueva, "los medios de tutela del acreedor", tal como ha sucedido en los borradores de los Principios Latinoamericanos de Derecho de los Contratos (en redacción), que ya se han colocado a disposición del público.

${ }^{2}$ En las obligaciones negativas, en principio, no sería factible constituir en mora al deudor pues no admitirían cumplimiento retrasado. Esta es la posición que toma el Código Civil en el artículo 1557 al establecer que se debe la indemnización de perjucios desde la constitución en mora del deudor, o desde el momento de la contravención a la obligación negativa. Con ello, se separa la mora para las obligaciones positivas, de la contravención en las negativas. Sin embargo, Díez-Picazo, Luis, Fundamentos de derecho civil patrimonial (Navarra, Thomson-Civitas, 2008), II: "Las relaciones obligatorias", p. 666, opina que es posible la constitución en mora del deudor, cuando el non facere se suspende a plazo, de tal suerte que tal obligación negativa podría retrasarse: 
ción de las obligaciones puras y simples que se regirían por la regla general (artículo 1551 No 3 CC.) $)^{3}$.

Así planteadas las cosas, la mora del deudor se ha transformado en una suerte de dogma: sin ella, no podrían ser ejercidos los medios de tutela. Y esto, a su vez, genera dos consecuencias. En primer lugar, establece un régimen muy estricto respecto del deudor. Con la sola llegada del plazo se abren los principales medios de tutela, quedando pocas posibilidades de escusa para el deudor. En lo fundamental el caso fortuito. Y, en segundo lugar, el acreedor sólo podría ejercer las acciones y remedios contractuales en la medida que el deudor se constituya en mora. De esta manera no le sería posible ejercer otros medios de tutela (anticipatorios a la llegada del plazo, si se quiere), porque todo el sistema de responsabilidad contractual, como ha sido configurado de la manera más clásica, gira en torno a la mora del deudor. Desde esta perspectiva, la mora del deudor puede ser considerada como la propia lesión del crédito.

Sin embargo, cuando se entra en un análisis comparativo es posible observar que la mora del deudor no tiene este carácter tan absoluto, ni menos de dogma. En primer lugar, porque en otras legislaciones de influencia europea continental no existe el régimen de mora automática, por lo menos, de la manera que como se ha configurado en el sistema chileno de responsabilidad contractual. Así, por ejemplo, el francés, que como se sabe sirvió de base para el nuestro en materia de obligaciones y contratos. Y en segundo lugar, porque la mora no está contemplada como requisito de operatividad de los remedios, como es la situación que se presenta en la esfera anglosajona y en los instrumentos de derecho contractual uniforme ${ }^{4}$, incluida la Convención de Viena sobre compraventa internacional de mercaderías (que ha sido ratificada

En contra, Palau Ramírez, Felipe - Pastor i Vicent, Manuel - Palau Sastre, Ana María - Talens Visconti, Eduardo Enrique, Presupuesto y efectos de la mora en Palau Ramírez, Felipe - Viciano Pastor, Javier (editores), Tratado sobre la morosidad (Cizur Menor, Aranzadi, 2012), p. 81, quienes sostienen que "cabría objetar que más que ante una obligación de no hacer, nos encontramos ante una obligación compleja: una obligación de no hacer precedida de una obligación positiva, como es la de poner fin a una determinada actividad mercantil o industrial. Desde esta perspectiva, la mora tendría lugar respecto de la obligación positiva que antecede al non facere":

${ }^{3}$ BARAona GonZÁlez, Jorge, Algunas consideraciones sobre el retraso en el cumplimiento de las obligaciones: su configuración y eficacia, en Pizarro Wilson, Carlos (coordinador), Estudios de Derecho Civil (Santiago, Legal-Publishing, 2008), IV, p. 383

${ }^{4}$ Nos referimos a Principios de Derecho Europeo de Contratos, Principios UNIDROIT sobre contratos comercial internacionales, Borrador para un Marco Común de Referencia; y la todavía reciente Propuesta del Parlamento Europeo sobre compraventa de 2011. 
e incorporada en nuestro ordenamiento interno) $)^{5}$. Basta en estos sistemas el retardo que constituye una de las diversas formas de incumplimiento.

Frente a esta realidad, la nacional y comparada, el presente trabajo pretende realizar una relectura dogmática sobre las normas del retraso y constitución en mora del deudor. La idea que se pretende manifestar en esta investigación es que la mora del deudor no se configura de modo tan amplio en el plano de sus efectos como la doctrina tradicional en Chile lo ha presentado. En concreto, se tratará de demostrar que: $i$ ) no todos los remedios contractuales se activan con la sola llegada del plazo, como sinónimo de la constitución en mora; ii) no toda indemnización de perjuicios requiere de la mora del deudor, sino solo la indemnización moratoria; iii) la mora sí mantiene una función de traslación de los riesgos al deudor por el efecto perpetuador que ella apareja, cual es su función propia. Desde esta perspectiva, la mora puede considerarse sólo como un retardo jurídicamente calificado, pero no la propia lesión del crédito. Por tanto, la opción interpretativa que se sigue en este trabajo de las normas sobre retraso y constitución en mora del deudor desde el plano dogmático puede ser considerada como restrictiva frente al planteamiento general. Se trata de ajustar el sentido y alcance de las normas sobre mora al sentido más literal del Código.

Para estos efectos, en primer lugar, se realizará un repaso sobre los efectos de la mora según la opinión común existente en Chile (I). Luego, se harán presentes las dificultades que apareja esta interpretación (II). Para, en tercer lugar, ofrecer una lectura restrictiva que permita solucionar las dificultades antes denunciadas (III). Terminará la investigación con las conclusiones que el trabajo pretende obtener.

\section{LOS EFECTOS DE LA MORA DEL DEUDOR SEGÚN LA DOCTRINA TRADICIONAL}

Tal como se ha venido introduciendo, la doctrina tradicional ha configurado la mora del deudor como un supra requisito de responsabilidad contractual en sentido amplio. El presente apartado pretende dar muestra de ello. Para estos efectos se comenzará repasando los efectos de la mora del deudor en relación a la indemnización de perjuicios (1). Ello, porque de alguna manera este análisis ha determinado para parte importante de la doctrina mayoritaria el resto del sistema de responsabilidad contractual. Luego, entonces, se analizará la incidencia de la cuestión en el resto de los

${ }^{5}$ Sobre el particular, véase: Palau Ramírez, Felipe - Corberá Martínez, José Miguel, La morosidad en los instrumentos internacionales, en Palau Ramírez, Felipe - Viciano Pastor, Javier (editores), cit. (n. 2), pp. 29 ss. 
principales medios de tutela: cumplimiento, resolución y excepción de contrato no cumplido (2). Y, posteriormente, se tratará el resto de los efectos de la mora del deudor (3 y 4 ).

\section{El pretendido efecto principal de la mora del deudor: Activa toda indem-} nización de perjuicios.

La doctrina se encuentra prácticamente conteste que a partir del artículo 1557 CC. exige la constitución en mora del deudor para la indemnización de todos los perjuicios, tanto compensatorios como moratorios ${ }^{6}$. De esta manera, la mora del deudor encuentra su sistematización entre nuestros autores dentro del régimen de responsabilidad contractual en sentido estricto ${ }^{7}$.

Sin embargo, la doctrina no se encuentra del conteste cuál es la función especifica que cumple la mora para los perjuicios compensatorios.

Así, Luis Claro ya enunciaba una antigua discusión que se produjo en el derecho francés a propósito del artículo $1146 \mathrm{CCFr}$ que es el equivalente a nuestro artículo 1557. La discrepancia tornaba sobre la necesidad de mora del deudor para la indemnización de los perjuicios compensatorios. Según la opinión de Laurent, seguida por Claro, si la mora tiene por objeto comprobar sólo el retardo del deudor, no podría ser sino exigida en los casos en que la inejecución proviene del simple retardo ${ }^{8}$. Sin embargo, contrario a la opinión de los juristas franceses, Claro fue del parecer siguiendo el texto de la ley chilena (bajo el pretexto que ser más preciso que en el modelo francés) que el Código exigiría mora tanto para los perjuicios compensatorios

${ }^{6}$ Claro Solar, Luis, Explicaciones de derecho civil chileno y comparado (Santiago, Editorial Jurídica de Chile, 2013), V: “De las obligaciones", 2 (volumen $11^{\circ}$ de la primera edición), \$1227, p. 644; Abeliuk Manasevich, René, Las obligaciones ( $6^{a}$ edición, Santiago, Legal-Publishing, 2014), II, p. 1000; Fueyo Laneri, Fernando, Cumplimiento e incumplimiento de las obligaciones (Santiago, Editorial Jurídica de Chile, 2004), p. 440; Gatica Pacheco, Sergio, Aspectos de la indemnización de perjuicios por incumplimiento de contrato (Santiago, Editorial Jurídica de Chile, 1959), p. 82; MEZA Barros, Ramón, Manual de derecho civil. De las obligaciones (10ª edición, Santiago, Editorial Jurídica de Chile, 2007), pp. 132; Ramos Pazos, René, De las obligaciones (3a edición, Santiago, Legal-Publishing, 2008), p. 280.

${ }^{7}$ Claro Solar, L., cit. (n. 6). V, 2, \$1221, p. 644; Abeliuk Manasevich, R, cit. (n. 6), II, p. 950; Gatica Pacheco, Sergio, Aspectos de la indemnización de perjuicios por incumplimiento de contrato (Santiago, Editorial Jurídica de Chile, 1959), pp. 59-60; Meza Barros, R., Manual, cit. (n. 6), p. 121; Ramos Pazos, R., De las obligaciones, cit. (n. 6), p. 243; Fueyo LANERI, F., Cumplimiento, cit. (n. 6), p. 361

${ }^{8}$ Claro Solar, Luis, cit. (n. 6), V, 2, \$1227, p. 644. Esta misma opinión se mantiene hasta hoy en doctrina francesa. Véase a título de ejemplo, Malaurie, Philippe - Aynès, Laurent - Stoffel-Munk, Philippe, Les obligations ( $4^{a}$ edición, Paris, Defrénois, 2009), pp. 527-528. 
como moratorios ${ }^{9}$. En el mismo sentido se pronunciaba Alessandri contra la opinión de los autores franceses. Sostenía este autor que como el Código no distinguió la exigencia de mora sólo para los perjuicios moratorios, al intérprete no le es lícito distinguir ${ }^{10}$.

La voz discordante entre estos autores contemporáneos la llevó Barros Errázuriz. Este autor, al tratar las formas de incumplimiento, distinguía entre incumplimiento absoluto, cumplimiento imperfecto y retardo culpable. En todas las clases de incumplimiento reconocía el derecho del acreedor para demandar los perjuicios. Sin embargo, únicamente exigía la mora para el caso de retardo culpable. Decía Barros Errázuriz que: "Hay retardo culpable en el cumplimiento de la obligación, que importa violación del derecho del acreedor, cuando el deudor está en mora [...] advirtiendo desde luego que el simple retardo no impone, por sí solo, obligación de indemnizar perjuicios si el deudor no se encuentra constituido en mora". Continúa: "en el caso de retardo culpable procede la indemnización moratoria, o sean de los perjuicios causados al acreedor por el cumplimiento tardío de la obligación ${ }^{11}$. Para la indemnización compensatoria no exigió expresamente la constitución en mora del deudor ${ }^{12}$.

Esta opinión terminó siendo aislada en la doctrina al punto que los autores más modernos no llegaron a cuestionarse si la constitución en mora del deudor debía o no ser un requisito necesario de toda indemnización de perjuicios, compensatoria o moratoria ${ }^{13}$, o a lo más enunciar su opinión discordante ${ }^{14}$.

El resultado es que no se ha llegado a discutir qué función cumple la mora,

${ }^{9}$ Claro Solar, Luis, cit. (n. 6), V, 2, \$1227, p. 644

${ }^{10}$ Alessandri Rodríguez, Arturo, Teoría de las obligaciones (Versión taquigráfca de sus clases por Ramón Latorre) (Santiago, Zamorano y Caperán, 1939), p. 83. En el mismo sentido: Gatica Pacheco, Sergio, Aspectos de la indemnización de perjuicios por incumplimiento de contrato (Santiago, Editorial Jurídica de Chile, 1939), p. 84.

${ }^{11}$ Barros Errázuriz, Alfredo, Curso de derecho civil (Santiago, Editorial Nascimento, 1932), II, p. 66.

${ }^{12}$ Ibíd., p. 65. Reseñan esta opinión sin compartirla: Claro Solar, L., cit. (n. 6), V, 2, \$1227, p. 644 n. 529; y Alessandri Rodríguez, A., cit. (n. 10), p. 83.

${ }^{13}$ Meza Barros, Ramón, Manual, cit. (n. 6), p. 132.; Barcia Lehmann, Rodrigo, Lecciones de derecho civil chileno (Santiago, Editorial Jurídica, 2008), III: "De la teoría de las obligaciones”, p. 105. Cabe hacer presente que Rodríguez Grez, Pablo Responsabilidad contractual (Santiago, Editorial Jurídica de Chile, 2003), pp. 136-140, se aleja parcialmente del marco conceptual sobre el que trabajan todos los autores. Este autor incluye la prestación a tiempo como un elemento propio de la prestación. De aquí que la constitución en mora del deudor es encuadrada por el autor dentro de uno de los presupuestos de la responsabilidad contractual: la inejecución de la conducta debida: Con todo, le reconoce su carácter de requisito, pero no de presupuesto.

${ }^{14}$ Ramos Pazos, R., De las obligaciones, cit. (n. 6), p. 280. 
ya que aparentemente toda indemnización de perjuicios exigiría constitución en mora del deudor. Como se puede apreciar de las lecciones de Claro y Alessandri expuestas unas líneas atrás, la exigencia aparente de mora en todos casos ha llevado a entender que como es siempre un requisito de la indemnización de los perjuicios, entonces, por lo menos impone la necesidad (formal) de interpelación al deudor, y desde la interpelación se debe la indemnización de perjuicios. Probablemente, la supuesta introducción de la regla "dies interpellat pro homine" en el artículo 1551 (si es que esta interpretación fuera la correcta, lo que será discutido en líneas posteriores), ha colaborado sustancialmente a la ausencia de debate toda vez que en la práctica la constitución en mora del deudor se produce por el vencimiento del plazo pactado.

Por tanto, de los argumentos de los autores puede expresarse que la mora del deudor cumple una primera función en relación a la indemnización de perjuicios: la de activación del remedio contractual ${ }^{15}$.

Sin embargo, hay dos autores que han manifestado una opinión un tanto más reflexiva en lo tocante a la función de la constitución en mora del deudor. En primer lugar es necesario citar la autoridad de Fueyo. Este autor sostiene que pueden reclamarse los perjuicios desde el deudor se constituye en mora de cumplir, pero ello no implica que los perjuicios se hayan producido antes de tal evento ${ }^{16}$. Abeliuk, en cambio, distingue entre indemnización compensatoria y moratoria ${ }^{17}$. La primera se debe desde el incumplimiento, la segunda desde la constitución en mora (aunque señala que el tema "dista de ser claro" $)^{18}$. En lo que importa para los efectos de los perjuicios resolutorios es que la opinión de estos últimos autores, aunque le reconocen el efecto de la mora como el hecho generador de los perjuicios, se cuestionan sobre el momento a partir del cual se generan los perjuicios. En opinión de estos

${ }^{15}$ Desde esta perspectiva, la mora sería entonces la propia lesión en el crédito que activa el remedio. Véase Díez-Picazo y Ponce de León, Luis, El retardo, la mora y la resolución de los contratos sinalagmáticos, en Anuario de Derecho Civil, 22 (1969) 2, pp. 401-402.

${ }^{16}$ Fueyo Laneri, F., cit. (n. 6), pp. 443-444.

${ }^{17}$ Abeliuk Manasevich, R, cit. (n. 6), II, pp. 1009-1010.

${ }^{18}$ Ibíd., II, p. 1010 el autor cita al respecto el artículo 1672 en que en caso de pérdida culpable o durante la mora del deudor la obligación subsiste pero varía de objeto y el deudor "es obligado al precio y a la indemnización de perjuicios". Dice Abeliuk: "El precio de la cosa es evidentemente indemnización compensatoria". AbELIUK, a nuestro parece confunde el valor de prestación (el precio) con la indemnización de perjuicios, tal como lo hace tradicionalmente la doctrina nacional. Por ello parece más convincente la fundamentación de Fueyo Laneri, F., cit. (n. 6), p. 444, (aunque el resultado interpretativo es el mismo) que se funda en la sistemática del Código en la sanción de lo injusto, que se produciría desde el incumplimiento contractual: 
autores, entonces, resulta por lo menos dudoso a partir del tenor literal del artículo 1557 que toda clase de perjuicios (compensatorios y moratorios) se generen a partir de la constitución en mora del deudor. Sin embargo, reconocen que la mora cumple un rol de activación de la indemnización de perjuicios. De la opinión de estos autores, se desprende que la mora puede cumplir una segunda función: la certificación del momento a partir del cual el acreedor sufre perjuicio por el retraso ${ }^{19}$.

La discusión doctrinaria descrita en el presente apartado, nos lleva a pesar que la constitución en mora del deudor puede tener roles o funciones diferentes y por tanto no existe una opinión común al efecto.

$\mathrm{Y}$ así, resumiendo los argumentos de la doctrina puede concluirse que no existe acuerdo en lo tocante a la función que cumple la constitución en mora del deudor en relación a la indemnización:

i) Según la opinión mayoritaria, la constitución en mora del deudor activa toda indemnización de perjuicios, moratoria y compensatoria, y los perjuicios se calculan desde este momento.

ii) Otros, en cambio, le confieren a la mora del deudor una función meramente formal en lo tocante a la activación indemnización de los perjuicios compensatorios, pues deben calcularse desde el incumplimiento; por el contrario, en los perjuicios moratorios la mora del deudor activa la indemnización de perjuicios y éstos se calculan desde que el deudor se ha constituido en mora.

iii) Por último, una opinión aislada en doctrina (Barros Errázuriz) estima que la mora del deudor sólo es requisito de activación de la indemnización moratoria, y a partir de ese momento se deben calcular estos perjuicios. En cambio, en lo tocante a la indemnización compensatoria no debe constituirse en mora al deudor puesto que los perjuicios no se calculan por el retraso, y por tanto desde el incumplimiento.

\section{Activa otros medios contractuales de tutela del acreedor.}

Como se ha también introducido, la doctrina estima en general que la mora del deudor es un requisito de los demás remedios principales del acreedor: el cumplimiento, la resolución y la excepción de contrato no cumplido. Abordaremos el problema desde la perspectiva de cada uno de los remedios.

a) El cumplimiento y la resolución. Antes tratar la cuestión, es necesario hacer presente que parte del problema que hacemos presente se da porque el Código no disciplina orgánicamente el cumplimiento de la

${ }^{19}$ La mora, desde este punto de vista constituiría una forma de retardo calificado, no la lesión en el crédito. Véase Díez-Picazo y Ponce de León, L., cit. (n. 15), pp. 402-403. 
obligación, ya específico, ya por equivalencia ${ }^{20}$. Frente a esta ausencia de tratamiento, nuestra doctrina ha construido la pretensión de cumplimiento desde dos perspectivas. Una sustantiva, a partir delos artículos 1553 y 1489 , y demás que confieren al acreedor la opción entre cumplimiento y resolución $^{21}$. Y otra procedimental, a partir de las normas del juicio ejecutiv ${ }^{22}$. Esto ha producido que en definitiva parte de la construcción de la pretensión de cumplimiento se interprete según el régimen de la indemnización de daños.

Lo que en apariencia resulta ser muy distante (el cumplimiento de la indemnización), para parte de la doctrina no lo es tanto. Un sector de la doctrina estima que la indemnización de daños es el denominado "cumplimiento por equivalente" (que sería un derecho secundario del acreedor, por lo menos en las obligaciones de dar ${ }^{23}$. Sería la misma obligación incumplida pero que cambia de objeto. Y esta indemnización ("cumplimiento por equivalente"), en consecuencia, sí estaría sujeta a la constitución en mora del deudor según lo dicho más arriba. Luego entonces, el cumplimiento y la indemnización estarían sujetos a los mismos requisitos: incumplimiento, culpa del deudor (no nos referiremos sobre este requisito pues sería parte de un estudio separado) y lo que nos importa, la mora del deudor.

El artículo 1553 lo exige para las obligaciones de hacer ${ }^{24}$. Pero, para las obligaciones de dar, no lo menciona el artículo 1489. Por ello, se recurre al artículo 1826 inciso $2^{\circ}$ y 1873 . El primero alude al retraso del vendedor en entregar la cosa, y el segundo, de manera explícita para a la mora del deudor ${ }^{25}$. De aquí es que para ambos remedios se requeriría la mora. Reconocemos, en todo caso, que el problema ha sido estudiado con mayor detención para la resolución que para la pretensión de cumplimiento. Sin embargo, según esta lectura sería ilógico pensar que el requisito estaría estructurado solo

${ }^{20}$ Vidal Olivares, Álvaro, La pretensión de cumplimiento especifico y su inserción en el sistema de remedios por incumplimiento en el Código Civil, en CORRAL TALCIANI, Hernán - Rodríguez Pinto, María Sara (editores), Estudios de Derecho Civil (Santiago, LexisNexis, 2007), II, pp. 517-537.

${ }^{21}$ Vidal Olivares, Álvaro, La pretensión de cumplimiento especifico y la responsabilidad por incumplimiento. Un intento de sistematización en el Código Civil, en PIZarro Wilson, Carlos - Vidal Olivares, Álvaro, Incumplimiento contractual, resolución e indemnización de daños (Bogotá, Editorial Universidad del Rosario, 2010), p. 285.

${ }^{22}$ Ibíd., p. 285.

${ }^{23}$ Claro Solar, L., cit. (n. 6), V, 2, §1199, p. 616; Abeliuk Manasevich, R., cit. (n. 6), II, p. 938; Fueyo Laneri, F., cit. (n. 6), pp. 341 ss.

${ }^{24}$ Claro Solar, Luis, cit. (n. 6), V, 2, \$1196, p. 613.

${ }^{25}$ Para la obligación de entrega: Alessandri Rodríguez, Arturo, De la compraventa y de la promesa de venta (Santiago, Editorial Jurídica, 2003), I, 2, pp. 782 ss.; para la obligación de pago del precio: íbid., II, 1, p. 361 ss. 
para la resolución con prescindencia del cumplimiento. Lo anterior es sin perjuicio de lo que señalará en el apartado siguiente sobre la excepción de contrato no cumplido.

Por otra parte, cabe anotar que estas opiniones están enmarcadas en aquellas doctrinas que sostienen que el incumplimiento, en sí mismo considerado, es una suerte de hecho ilícito. Luego, la mora, como sinónimo de inejecución, también sería requisito de la pretensión de cumplimiento, puesto que la responsabilidad contractual, en sentido amplio, se fundaría en general en las nociones de culpa o dolo ${ }^{26}$, y la mora tradicionalmente se define como un retardo culpable en el cumplimiento de una obligación.

b) La excepción de incumplimiento contractual o "exceptio non adimpleti contractus". El cuarto medio de tutela que requeriría de la constitución en morapara su activación es la excepción de incumplimiento contractual. Parte importante de la doctrina nacional sostiene que este remedio está recogido en el artículo 1552 CC., o por lo menos, contiene las bases para su aplicación.

Según el tenor literal de la norma, cuando ambos contratantes no han dado cumplimiento a sus obligaciones en un contrato bilateral, ninguno está en mora de cumplir ("la mora purga la mora"). Por lo tanto, se requeriría de la mora de ambos contratantes para la activación, puesto que ambos son deudores recíprocos.

En el plano de los efectos de la norma, la ausencia de mora por incumplimiento recíproco impediría el ejercicio de la pretensión de cumplimiento (específico o por equivalencia), la resolución del contrato (para una doctrina más clásica aunque en retirada) y la indemnización de perjuicios ${ }^{27}$.

Lo importante que cabe destacar es que la configuración del remedio, tal como lo ha hecho parte importante de la doctrina es que estaría en plena concordancia con el ejercicio de los remedios "principales": la mora recíproca impediría el ejercicio de la pretensión de cumplimiento ${ }^{28}$. De aquí se colige

${ }^{26}$ Así, por ejemplo, se configura en la reciente edición de la obra de Las Obligaciones de Abeliuk, desde el plano del incumplimiento: Abeliuk Manasevich, R., cit. (n. 6), II, p. 924; y de la mora como retardo "imputable": ibíd., II, p. 1000.

${ }^{27}$ Hemos tratado esto antes en Contardo González, Juan Ignacio, Procedencia de la indemnización por incumplimiento reciproco, en Departamento de Derecho Privado Universidad de Concepción (Coordonador), Estudios de Derecho Civil (Santiago, Abeledo Perrot - LegalPublishing, 2010), V, pp. 541-551

${ }^{28}$ En contra, se manifiesta CAPRILE BIERMANN, Bruno, Algunos problemas ofrecidos por la excepción de contrato no cumplido y, en especial, el de su invocación para atajar la acción resolutoria en el caso de incumplimiento reciproco de los contratantes, en Revista de Derecho de la Pontificia Universidad Católica de Valparaiso, 39 (2012), p. 80, quien sostiene que la mora no es requisito de la pretensión del cumplimiento, lo que se vería refrendado por el artículo 1537 CC. 
que la pretensión de cumplimiento requeriría la constitución en mora del deudor, agregando un argumento adicional al descrito más arriba. Por otra parte, impediría ejercer la resolución ${ }^{29}$. Se sostiene por varios autores que el resolvente debe ser considerado como contratante "diligente", de tal manera que debe haber cumplido su obligación o debe estar llano a cumplirla. De esta manera, si no lo ha hecho, no podría solicitar la resolución por incumplimiento. $Y$ en tercer lugar, impide el ejercicio de toda indemnización de perjuicios, ya que no se configuraría el requisito establecido en el artículo $1557^{30}$.

\section{Invierte la regla de riesgos.}

Este es un tercer efecto que se le asigna en general a la mora del deudor. Según la regla general, si acaece el caso fortuito destruyendo el cuerpo cierto cuya entrega se deba, el acreedor sufre el riesgo por lo que es obligado todavía a cumplir su parte en el contrato. Por tanto, a pesar de la pérdida fortuita de la especie que constituye el objeto de la obligación de una de las partes, el contrato legalmente mantiene su vigencia. Si se mira desde el punto de vista del incumplimiento, objetivamente lo hay puesto que no se cumple la obligación. Lo que sucede es que resulta excusable este incumplimiento para el deudor. De esta suerte, al acreedor le sería vedado solicitar la resolución del contrato, puesto que legalmente el contrato mantiene vigencia ${ }^{31}$.

Constituye excepción a la regla de riesgos "resperit creditori" del artículo 1550 CC. que el deudor se haya constituido en mora de efectuar la entrega de la cosa cuya entrega se deba. Esta alteración de la regla de riesgos es colocada en manos del deudor. Esto significa que frente al acaecimiento del riesgo, el deudor sufrirá la pérdida como dueño, y el acreedor (deudor de la obligación correlativa), no estará obligado a cumplir.

Lo importante para estos efectos es que la mora del deudor implica que el deudor haya estado obligado cumplir e incumplió su obligación, puesto que la entrega todavía se debe bajo los efectos del mismo artículo ("cuya entrega se deba"). Más todavía: la entrega era exigible, de tal suerte que el deudor alcanzó a constituirse en mora (de lo contrario se regiría por la regla del ar-

${ }^{29}$ Para una panorámica expuesta dentro de los autores más recientes, puede verse Contardo González, J. I., Procedencia, cit. (n. 27), pp. 541-551; Caprile BierMANN, B., cit. (n. 28), pp. 81 ss.; y Mejías Alonzo, Claudia, La excepción de contrato no cumplido y su consagración en el Código Civil chileno, en Revista Chilena de Derecho, 40 (2013) 2, pp. 389-412

${ }^{30}$ Abeliuk Manasevich, R., cit. (n. 6), II, p. 1002.

${ }^{31}$ Barros Bourie, Enrique, Finalidad y alcance de las acciones y los remedios contractuales, en Guzmán Brito, Alejando (editor), Estudios de Derecho Civil (Santiago, LegalPublishing, 2008), III, pp. 420-421. 
tículo 1670: la obligación se extinguiría). Por esta razón, la ley ha invertido la regla de riesgos colocándolo de manos del deudor, puesto que califica la mora del deudor como una especie de incumplimiento, de tal suerte que frente al caso fortuito que destruye la cosa, asume que la destrucción se ha producido porque el deudor no cumplió su obligación.

$\mathrm{Si}$ acaece el caso fortuito y la regla de riesgos se invierte por efecto de la mora del deudor, entonces, cabe aplicar la regla general del artículo 1672: se debe el precio y la indemnización de perjuicios, puesto que la ley ha calificado que el caso fortuito durante el estado de mora del deudor no extingue el incumplimiento de este mismo.

\section{Hace responsable al deudor por el caso fortuito.}

De forma coincidente con el efecto anterior, la mora del deudor lo hace "responsable" por el caso fortuito en virtud de lo dispuesto en los artículos 1547 y 1672 CC.

El artículo 1547 inhciso $2^{\circ}$ dispone: "El deudor no es responsable del caso fortuito, a menos que se haya constituido en mora (siendo el caso fortuito de aquellos que no hubieran dañado a la cosa debida, si hubiese sido entregada al acreedor), o que el caso fortuito hay a sobrevenido por su culpa". Por su parte el artículo 1672 inciso $2^{\circ}$, en el mismo sentido prescribe: "Sin embargo, si el deudor está en mora y el cuerpo cierto que se debe perece por caso fortuito que habría sobrevenido igualmente a dicho cuerpo en poder del acreedor, sólo se deberá la indemnización de los perjuicios de la mora. Pero si el caso fortuito pudo no haber sucedido igualmente en poder del acreedor, se debe el precio de la cosa y los perjuicios de la mora".

De la lectura de ambas normas se articula la "responsabilidad" del deudor moroso de la siguiente manera ${ }^{32}$ :

i) El deudor moroso "responde" del caso fortuito (artículo 1547 inciso $2^{\circ}$ ). En este caso, la "responsabilidad" del deudor alcanza el "precio" y la "indemnización de perjuicios" (artículo 1672 inciso $2^{\circ}$ parte final). La constitución en mora del deudor produce la perpetuación de la obligación ${ }^{33}$, por lo que se debe "el precio" (la obligación perpetuada), más la indemnización de los perjuicios.

ii) Pero si el caso fortuito hubiese acaecido igualmente en poder del acreedor, sólo responderá de los perjuicios moratorios (artículo 1672 inciso $2^{\circ}$ ). Es

${ }^{32}$ Reconfiguramos la esquemática explicación que Abeliuk MANASEvich, R., cit. (n. 6), II, pp. 1010-1011 nos brinda al efecto:

${ }^{33}$ BARAONA GonzÁLEZ, Jorge, Responsabilidad contractual y factores de imputación de daños: apuntes para una relectura en clave objetiva, en Revista Chilena de Derecho, 24 (1997) 1, pp. 159-162. 
decir, el caso fortuito aquí cumple un fin de evitación de la perpetuación de la obligación, sin embargo no lo exime del pago de los perjuicios moratorios.

Si se lee con detención la configuración de la "responsabilidad" (en sentido amplio) del deudor moroso por el caso fortuito, da la impresión que ella se articula a partir de la frustración de la pretensión de cumplimiento por el caso fortuito que ha acaecido durante la mora del deudor. Por ello es que la "responsabilidad" alcanza, por regla general, al "precio" y a la "indemnización de perjuicios". Queremos hacer notar que esta indemnización de perjuicios el Código la califica como moratoria, toda vez que en caso de que el caso fortuito hubiere sobrevenido igualmente en manos del acreedor, se deben estos perjuicios, no los compensatorios.

\section{LAS DIFICULTADES QUE PRESENTA}

\section{LA CONFIGURACIÓN CLÁSICA DE LA MORA DEL DEUDOR}

En el apartado anterior hemos descrito cómo la mora del deudor se ha configurado como uno de los requisitos esenciales de ejercicio de los remedios de tutela del acreedor (por lo menos de los de más frecuente ejercicio en la práctica); y cómo ella se articula en el régimen de imposibilidad según la regla de riesgos y de perpetuación de la obligación.

En este apartado trataremos las dificultades que apareja la constitución en mora del deudor según esta construcción general. Para estos efectos, creemos conveniente, primero, analizar el supuesto recogimiento de la regla "dies interpellat pro homine" en el artículo $1551 \mathrm{~N}^{\circ}$ s 1 y 2 (1); para luego analizar los problemas de aplicación en el campo de los remedios. Así, se verá que la mora, según la configuración más clásica, se erige como un requisito formal de operatividad de los medios de tutela, lo que hace en definitiva que el análisis sobre la verdadera importancia de la mora del deudor pase a un lugar secundario (2). Asimismo se dejará en evidencia que esta regla de constitución automática no sirve para analizar otros incumplimientos relevantes, en especial, el cumplimiento imperfecto (3). Y, por último, esta interpretación no recoge la distinción de plazo esencial y no esencial, que puede ser de utilidad para determinar los efectos de la mora del deudor.

\section{Un cuestión previa: La supuesta inclusión de la regla "dies interpellat pro} bomine" en el artículo 1551 CC.

Según la doctrina más uniforme en nuestro país, el artículo 1551 consagraría la regla según la cual la sola llegada del plazo constituiría en mora el deudor ${ }^{34}$. A esta regla se le reconoce por el aforismo "dies interpellat pro

\footnotetext{
${ }^{34}$ Ramos Pazos, R., cit. (n. 6), pp. 83-284; Meza Barros, R., cit. (n. 6), p. 134;
} 
homine", que quiere decir que el tiempo interpela por el hombre. El recogimiento de esta regla se opone a la interpelación personal (ex persona), que exige una notificación del acreedor hacia el deudor del retraso en el cumplimiento de una obligación. De ahí que la llegada del plazo sustituye a la interpelación personal.

En nuestro país,en general, se sostiene que en el artículo 1551 estaría recogida la regla de interpelación por la sola llegada del plazo ("dies interpellat por homine"). La conclusión se desprendería del tenor literal de la norma, en sus numerandos 1 y 2 .

Para los efectos de explicar debidamente la interpretación que se la ha dado al art'piculo 1551 CC., conviene reproducirlo: "El deudor está en mora,/ 1. Cuando no ha cumplido la obligación dentro del término estipulado, salvo que la ley en casos especiales exija que se requiera al deudor para constituirle en mora; 2. Cuando la cosa no ha podido ser dada o ejecutada sino dentro de cierto espacio de tiempo, y el deudor lo ha dejado pasar sin darla o ejecutarla".

La conclusión a la que se ha llegado es que cuando existe un plazo pactado en el contrato, o bien, no habiéndose pactado de manera expresa pero implícito en el mismo (plazo tácito: artículo 1494), su llegada produce la constitución en mora del deudor ${ }^{35}$. Esto es lo que se desprendería de la lectura literal de la norma: el deudor estaría en mora cuando ha llegado el plazo expreso (numeral uno), o tácito (numeral dos).

El sistema entonces se configuraría como de mora automática, también llamada mora $e x r e^{36}$. La sola llegada del plazo permite la constitución en mora del deudor, sin necesidad de una interpelación especial por parte del acreedor.

Es necesario recordar que la mora del deudor, al menos, tiene dos ele-

Barcia Lehmann, R., cit. (n. 6), p. 107; Fueyo Laneri, F., cit. (n. 6), p. 449; AbeLiUk MANASEVICH, R., cit. (n. 6), II, pp. 1006 ss.

${ }^{35}$ Sobre el particular, revísese: "Cuevas con Unión Médica de Santiago", Corte Suprema, 27 de noviembre de 1911, sin rol, acción de resolución de donación, citada en LegalPublishing: CL/JUR/2/1911; "Rodríguez y otro contra Empresa de Ferrocarriles del Estado”, 10 de marzo de 1943, sin rol, acción de resolución de donación, citada en LegalPublishing: CL/JUR/4/1943. Más recientemente, "Garrido con Barahona", Corte de Apelaciones de Concepción, 30 de agosto de 2004, rol 3469-2002, acción de indemnización de perjuicios, citada en LegalPublishing: CL/JUR/941/2004; "SP Inversiones e Informática Limitada contra Inversiones Valle Alegre Limitada”, Corte Suprema, 8 de abril de 2008, rol 5145-2006, acción ejecutiva de cumplimento, citada en LegalPublishing: CL/JUR/899/2008; “Aguayo con Corpbanca”, Corte Suprema, 25 de julio de 2012, rol 5540-2011, juicio ordinario de cumplimiento, citada en LegalPublishing: CL/JUR/1507/2012; "Comercializadora Hong Kong Limitada con Banco Santander Chile”, Corte Suprema, 20 de agosto de 2012, rol 3097-2012, (acción de cumplimiento), citada en LegalPublishing: CL/JUR/1781/2012.

${ }^{36}$ Díez-Picazo Giménez, Gema, La mora y la responsabilidad contractual (Madrid, Civitas, 1996), p. 539. 
mentos copulativos: el retraso y la interpelación del acreedor (descontamos imputabilidad en el retraso que es discutida como tercer elemento ${ }^{37}$ ). Así, en las situaciones descritas en los numerales 1 y 2 del artículo 1551 no sería necesaria la interpelación, se produciría de forma automática, con la sola llegada del plazo.

Para aquellos autores partidarios de esta interpretación, la construcción de la regla del artículo 1551 habría variado, en lo sustancial, de los antecedentes que Bello habría tenido a la vista (no hay nota de Bello en los proyectos), configurándose la regla como de mora automática en vez de previa interpelación, como lo establecían el Código francés y el proyecto de García Goyena ${ }^{38}$. Al parecer, se habría seguido en esto más de cerca al sistema de las Partidas que sí contemplaba un sistema de mora automática ${ }^{39}$.

${ }^{37}$ El presente trabajo no discutirá sobre el particular. En el medio nacional, en general se define la mora del deudor como un retraso imputable al deudor sumado al requerimiento expreso o tácito al deudor. Esta parece ser la opinión común entre los autores nacionales. A título de ejemplo, véase: Claro Solar, L., cit. (n. 6), V, 2, § 1227, p. 644; Meza Barros, R., cit. (n. 6), p. 133; Barcia Lehmann, R., cit. (n. 6), p. 106; Ramos Pazos, R., cit. (n. 6), p. 282; Abeliuk Manasevich, R., cit. (n. 6), II, pp. 1001 ss. La conclusión se vería corroborada por el artículo 1558 injciso $2^{\circ}$ que establece que "La mora producida por fuerza mayor o caso fortuito no da lugar a indemnización de perjuicios". De esta suerte, si el caso fortuito excluye la culpa del deudor, luego, el incumplimiento (retraso) debiera ser imputable al deudor. Sin embargo, el tema es discutido, en doctrina extranjera: De LARA Morales, Julio Manrique, La mora del deudor en las obligaciones civiles de hacer (Madrid, Centro de Estudios Registrales, 2001), pp. 231-233.

${ }^{38}$ El Código francés en su artículo 1146 regula la necesidad de mora del deudor para la indemnización de perjuicios: "Les dommages et intérêts ne sont dus que lorsque le débiteur est en demeure de remplir son obligation, excepté néanmoins lorsque la chose que le débiteur s'était obligé de donner ou de faire ne pouvait être donnée ou faite que dans un certain temps qu'il a laissé passer". La norma, sufrió una agregación por la Ley $\mathrm{N}^{\circ}$ 91-650, de 9 julio de 1991, que agregó una parte final al artículo, en el mismo inciso: "La mise en demeure peut résulter d'une lettre missive, s'il en ressort une interpellation suffisante". La reforma reafirma la necesidad de interpelación. Por su parte, el "Proyecto de García Goyena” establecía lo siguiente en su artículo 1007: "Para que el obligado a entregar una cosa se constituya en mora, debe mediar requerimiento por parte del acreedor, excepto en los casos siguientes:/ $1 .^{\circ}$ Cuando en el contrato se haya estipulado expresamente que el solo vencimiento del plazo lo produzca, sin necesidad de requerimiento./ $2{ }^{\circ}$ Cuando de la naturaleza y circunstancias del contrato resulte que la designación de la época en que debia entregarse la cosa, fue un motivo determinante, por parte del que habia de recibirla, para celebrarlo./ En las obligaciones reciprocas ninguno de los contratantes incurre en mora, si el otro no lo cumple ó no se allana a cumplir debidamente la obligación que le es respectiva./ Cuando hay mora, por parte de los dos contratantes, perjudica la posterior": García Goyena, Florencio, Concordancias, motivos y comentarios del Código Civil español (Madrid, Imprenta de la Sociedad Tipográfico-Editorial, 1852), III, p. 45.

${ }^{39}$ Claro Solar, L., cit. (n. 6), V, 2, § 1234, pp. 653-655. Como explica este mis- 
La historia de la ley indica que Bello cambió la redacción originaria del artículo, lo que podría ser indiciario del seguimiento del sistema de mora automática. Hay dos antecedentes relevantes.

El primer, y más remoto, es el "Proyecto de 1842", cuyo artículo 5 del título $11^{\circ}$ decía: "El deudor está en mora cuando no ha cumplido la obligación dentro del término estipulado, y en el contrato se expresa que, por la mera expiración del término, quedará constituido en mora (lo cual se entiende sin perjuicio de las leyes especiales que induzcan la mora por la simple expiración del término, o que requieran la reconvención judicial, no obstante cualquier expresión del contrato); cuando la cosa no ha podido ser dada o ejecutada sino dentro de cierto espacio de tiempo, y el deudor lo ha dejado pasar sin darla o ejecutarla; $y$ cuando el deudor ha sido judicialmente reconvenido por el acreedor. El que hurta se constituye en mora por el solo efecto del hurto". Como se puede observar, la redacción de la norma es muy similar al proyecto de García Goyena $^{40}$. La primera regla da a entender que sólo hay constitución en mora automática cuando las partes pactan que tal es el efecto que se producirá con el retraso. A falta de pacto, no hay constitución automática.

El segundo, es el "Proyecto de 1853", que en su artículo $1730 \mathrm{~N}^{\circ} 1^{\circ}$ establecía (el encabezado ya guardaba la redacción definitiva): "Cuando no ha cumplido la obligación dentro del término estipulado, si en el contrato se expresa que por la mera expiración del término quedará constituido en mora; salvo que la ley en casos especiales requiera la reconvención judicial no obstante cualquier expresión del contrato". En este proyecto, ya se guarda la expresión "término estipulado" pero mantiene la necesidad de pacto expreso para la constitución en mora ex re.

Como puede también observarse, la redacción definitiva del texto, que ya aparecía en el "Proyecto inédito" (artículo 1730), suprimió la oración "si en el contrato se expresa que por la mera expiración del término quedará constituido en mora", de tal suerte que, en apariencia, la norma habría quedado como de constitución moratoria automática pues se suprimió el pacto expreso.

mo autor, frecuentemente se señala que el sistema de mora automática según el aforismo "dies interpellat pro homine" sería de origen romano clásico, y fue seguido por las Partidas, pero no el francés: Claro Solar, L., cit. (n. 6), V, 2, \$1233, p. 653. Es necesario anotar que, en nuestro medio, Claro, cit. ibíd, $\$ 1231$, pp. 647-652, es el que mejor desarrolla la institución desde el punto de vista histórico, afirma que la regla "dies interpellat pro homine", no es propiamente romana, sino una elaboración doctrinal posterior. Por su parte, refrendando esta conclusión, Zimmermann, Reinhard, The Law of Obligations (Oxford, Oxford University Press, 1996), p. 798, aclara que el aforismo proviene de una generalización realizada por los glosadores a partir de un texto del Codex Iustinianus (CI. 8,37,12) que dispensaba de la interpelación (admonitio) cuando las obligaciones eran contraídas a día cierto.

${ }^{40}$ Véase la nota 38. 
Sin embargo, Luis Claro no fue de esta opinión ${ }^{41}$. Aclara el autor que la constitución en mora del deudor se produce cuando el plazo pactado es fatal, es decir, cuando se ha pactado que el cumplimiento de la obligación deba darse dentro de cierto término, tal como lo establece el artículo 49 del Código ("Cuando se dice que un acto debe ejecutarse en o dentro de cierto plazo, se entenderá que vale si se ejecuta antes de la medianoche en que termina el último día del plazo"). En efecto, la norma sugiere, con sutileza, que la constitución en mora se produzca sólo si las partes lo han pactado de esa manera, es decir, "Cuando no ha cumplido la obligación dentro del término estipulado". Con nitidez, Claro expresaba: "Esto no significa que el día interpele por el hombre en el sentido que tenía la regla de los glosadores que la aplicaban a toda clase de obligaciones a plazo". Tal como lo ha entendido la generalidad de la doctrina ya citada, e incluso la jurisprudencia que el mismo Claro denunciaba ${ }^{42}$.

Por lo anterior, en realidad el Código guardó concordancia con sus antecedentes normativos, en especial, el "Proyecto de García Goyena”. No hay constitución en mora ex re, sino cuando las partes han estipulado un plazo fatal para el cumplimiento de la obligación, o bien cuando la prestación no pueda sino cumplirse en la época prefijada, que indica asimismo fatalidad del plazo. Como se verá, el pacto del plazo de este carácter es concordante en pleno con la configuración de un sistema de incumplimiento esencial, que reconoce la existencia de plazos no fatales. La sola estipulación del plazo no es suficiente, sino requiere que las partes distribuyan sus riesgos en el sentido que se necesite una aclaración especial sobre la importancia del plazo para la constitución en mora del deudor. En todo caso, como se verá más adelante, la esencialidad del plazo genera para el Código consecuencias distintas para los efectos de obligaciones dinerarias y no dinerarias.

Esta opinión de Claro conviene tenerla muy presente para el resto los problemas interpretativos que denunciamos. No solo la compartimos, sino además cabría hacer una crítica, si se quiere excesiva, al texto del Código. So pretexto de ser muy técnico en la concordancia entre los artículos 49 y 1551 № 1 , el texto creemos que fue cándido en pensar que el aplicador descubriera el verdadero sentido de la norma concordando la redacción de tales artículos. $\mathrm{Al}$ punto que la doctrina y jurisprudencia se ha uniformado en que todo plazo vencido constituye en mora al deudor, como venimos describiendo.

Por lo tanto, puede concluirse que la norma merece una revisión interpretativa según los artículos 10 y 22 CC. Como se expresará en los próximos

${ }^{41}$ En lo sucesivo, reproducimos el planteamiento de Claro Solar, L., cit. (n. 6), $\mathrm{V}, 2, \$ 1235$, pp. 655-656.

${ }^{42}$ Ibíd., $\$ 1235$, pp. 655 n. 556 . Algunos de los fallos citados aparecen citados en la nota 35 . 
apartados, esta interpretación produce algunas distorsiones en el sentido que debe darse a los efectos de la constitución en mora del deudor.

\section{Función de la (supuesta) regla de mora automática, ¿requisito formal de} activación de los medios de tutela?

De lo que recién se viene describiendo según el pensamiento de la generalidad de los autores nacionales (con la importante excepción de Claro que reivindicamos), es decir, que con cualquier vencimiento del plazo el deudor se constituye en mora, se genera una consecuencia bien concreta: incumplimiento, retraso y mora se confunden ${ }^{43}$.

A pesar que nuestros autores se esfuerzan en distinguir estos tres estados ${ }^{44}$, la aplicación práctica de la interpretación sugerida para el artículo $1551 \mathrm{~N}^{\circ}$ 1 (y en parte el $\mathrm{N}^{\circ} 2$ ) produce que con cada retraso el deudor incumpla la obligación y por tanto se constituya en mora, generándose todos los efectos descritos con anterioridad ${ }^{45}$. Es decir, se debería toda indemnización de perjuicios, los otros remedios contractuales se activarían, se invierte la regla de riesgos, y se coloca en manos del deudor la responsabilidad por el caso fortuito.

De esta situación bien cabe preguntarse, entonces ¿para qué sirve la constitución en mora del deudor? ¿No bastaría entonces el retraso? De otra manera, si todo incumplimiento en razón del plazo produce la apertura de los remedios, ya que de ellos dependería la constitución en mora del deudor, entonces ¿qué función cumple la mora del deudor?

Piénsese en la pretensión de cumplimiento específico, ¿afecta la mora en la activación del remedio? Desde luego, cabría pensar que sí desde el momento en que la "exceptio non adimpleti contractus" exigiría la constitución en mora del deudor para el problema de los incumplimientos recíprocos. Pero ello no se contrasta con régimen de contratos unilaterales. En ellos, la mora recíproca no es relevante, por la sencilla razón que no hay obligación correspondiente. Por otro lado, en caso de imposibilidad no es relevante el retraso para la activación del remedio, sino más bien para determinar los efectos de la imposibilidad sobrevenida fortuita, en cuyo caso ésta no afecta la obligación cuando el deudor se ha constituido en mora. Pero ello, la mora no está relacionado con la activación del cumplimiento (al final del trabajo se volverá sobre esta idea).

Otro tanto sucede con la resolución, en que la mora del deudor no sirve

${ }^{43}$ Baraona GonZÁlez, Jorge, cit. (n. 3), p. 377

${ }^{44} \mathrm{Al}$ respecto, revísese dos textos de consulta frecuente que explican la cuestión con claridad: Abeliuk Manasevich, R., cit. (n. 6), II, p. 1006; Ramos Pazos, R., cit. (n. 8), p. 283.

${ }^{45}$ Véase más arriba I. 
para activar el remedio. Basta con el retraso, que será el momento para calificar si el deudor desplegó o no la conducta debida, es decir, si el incumplimiento es o no resolutorio. En otras palabras, el vencimiento del plazo para el cumplimiento de la obligación es necesario para la verificación si el incumplimiento reviste la gravedad suficiente para que tenga lugar la resolución.

Desde esta perspectiva, es del todo concordante que el artículo 1489 no exija la constitución en mora del deudor ni para el cumplimiento ni para la resolución contractual, sino solo el incumplimiento, que en las obligaciones a plazo más bien se identifica con el retraso, no con la mora del deudor que es un estado especial del incumplimiento que genera ciertos efectos adicionales relacionados con el traslado de los riesgos de la prestación incumplida hacia el deudor (artículos 1547 inciso $2^{\circ}$ y 1672 inciso $2^{\circ}$ ).

Si estamos en lo correcto, mantener una interpretación que designe que con la sola llegada del plazo el deudor se constituye en mora y por esa razón se activan los remedios, implicaría sostener que la mora del deudor es más bien un requisito formal de activación de los remedios ya que no se observa qué funcionalidad se le otorga a la mora del deudor.

Bien podría objetarse a esta conclusión que el Código sí exige la constitución en mora del deudor para activar el cumplimiento y la resolución en la compraventa, ya sea por falta de entrega de la cosa (artículo 1826 inciso $2^{\circ}$ ) o por no pago del precio (artículo 1873), argumentos agregados por Alessandri.

La primera de las normas enunciadas establece lo siguiente: "Si el vendedor por hecho o culpa suya ha retardado la entrega, podrá el comprador a su arbitrio perseverar en el contrato o desistir de él, y en ambos casos con derecho para ser indemnizado de los perjuicios según las reglas generales" [la cursiva es nuestra]. Alessandri ve en esta norma que la ley exige la constitución en mora del deudor, ya que alude este inciso al retraso, y a la indemnización según las reglas generales que exige mora del deudor (artículo 1557) ${ }^{46}$.

Sin embargo, el tenor literal de la norma no alude a la constitución en mora del deudor, sino al retraso. La norma se basa en el incumplimiento del vendedor de entregar una especie o cuerpo cierto, ya sea porque no la cumplió inmediatamente, o porque no la cumplió en el plazo establecido, que son las hipótesis del inciso primero ("El vendedor es obligado a entregar la cosa vendida inmediatamente después del contrato o a la época prefijada en él"). Aquí la constitución en mora del deudor es irrelevante. Y el reenvío de la norma a las reglas generales también, puesto que el Código ha separado el requisito de la resolución y del cumplimiento, el retraso, con los de la indemnización de perjuicios. Las reglas generales se exigen respecto de la indemnización

${ }^{46}$ Alessandri Rodríguez, A., cit. (n. 26), I, 2, pp. 782 ss. 
(la supuesta constitución en mora del deudor), no del cumplimiento ni la resolución. La norma es perfectamente coincidente con el artículo 1489.

La segunda norma a la que se hace alusión es el artículo 1873. Dice el artículo: "Si el comprador estuviere constituido en mora de pagar el precio en el lugar y tiempo dichos, el vendedor tendrá derecho para exigir el precio o la resolución de la venta, con resarcimiento deperjuicios". Aquí la constitución en mora del deudor parece ser requisito del ejercicio de los remedios de cumplimiento y resolución ${ }^{47}$. Sin embargo, una segunda lectura al artículo nos hace llegar a la conclusión contraria. La mora del deudor está en función del plazo que la misma norma establece. Nos encontramos frente a una obligación de dinero a plazo que ha sido incumplida. Así, el artículo parte de la base que el deudor ya se ha constituido en mora, es decir, que el deudor ha retrasado el pago del precio en una obligación a plazo. Empero, de acá no se colige que el artículo 1873 asimile el hecho del retraso a la mora del deudor. Menos aún se colige que la mora sea un requisito de activación de la resolución o del cumplimiento, siendo la norma muy excepcional. Al analizar de manera sistemática el Código, podemos señalar que la norma en comento alude a la mora del deudor para los efectos del cálculo de los perjuicios del incumplimiento de una obligación dineraria (el precio), lo que guarda consonancia con el artículo 1559, que se revisará con posterioridad.

\section{Los incumplimientos no cubiertos por la supuesta regla de la interpelación} automática.

Además de lo anterior, cabe hacer presente que hay incumplimientos no cubiertos por la supuesta interpelación automática: los que se generan a partir de las obligaciones puras y simples ${ }^{48}$, y lo que es más importante (los primeros son muy escasos), los cumplimientos defectuosos.

En el caso de los cumplimientos defectuosos, nos encontramos en la situación especial de una obligación que ha sido cumplida oportunamente, pero que la prestación no se ajusta al programa contractual ${ }^{49}$. Partimos de la base de cumplimientos defectuosos en un sentido más estricto, y no incorporamos las hipótesis de "aliud pro alio" que pueden reconducirse a casos de incumplimiento total de la prestación, y por tanto de retraso.

De nuevo es necesario formular la pregunta: en estos incumplimientos, ¿qué función cumple la mora (automática) del deudor? Desde cierto punto de vista, el vencimiento del plazo marca la época en que debía cumplirse

${ }^{47}$ Ibíd., pp. 361 ss.

${ }^{48}$ BARAona GonZÁlez, Jorge, cit. (n. 3), p. 383

${ }^{49}$ Mejías Alonzo, Claudia, El incumplimiento contractual y sus modalidades, en Guzmán Brito, Alejandro (editor), Estudios de Derecho Civil (Santiago, LegalPublishing, 2008), III, pp. 459 ss. 
con la obligación, y si la prestación ha sido ejecutada de manera imperfecta, entonces, no ha sido cumplida dentro de tiempo. Sin embargo, lo relevante frente a los incumplimientos imperfectos no es que la prestación no haya sido cumplida dentro del plazo, sino que ella contiene una defectuosidad que es propia de la prestación. Por esta razón, estos incumplimientos en realidad no se encuentra cubiertos por la supuesta regla de interpelación automática, y por tanto, cumplida la prestación dentro de plazo, pero imperfecta, el deudor no debiera constituirse en mora por la regla del artículo $1551 \mathrm{~N}^{\circ} 1$, aun cuando se estime que la mora opera ex re. Es decir, el deudor sólo se constituiría en mora en la medida que el acreedor le manifieste que la disconformidad de la prestación le causa daño, y ello sólo podría darse en la medida que interpele al deudor de conformidad al $\mathrm{N}^{\circ} 3$ del artículo 1551.

Por las consideraciones anotadas, en los instrumentos de derecho contractual uniforme se contempla la posibilidad que el deudor pueda rectificar o subsanar el cumplimiento defectuoso, aún cuando el plazo para el cumplimiento haya vencido. De esta manera, la Convención de las. Naciones Unidas sobre los contratos de compraventa internacional de mercaderías (artículo 48), los Principios UNIDROIT sobre contratos comercial internacionales (artículo 7,1,4), los Principios de derecho europeo de contratos (artículo 8: 104) y el Borrador para un marco común de referencia (artículos III, 3: 201 a III, 3: 204) exigen que en aquellos casos en que el plazo para el cumplimiento no es esencial, no se produce un incumplimiento definitivo de la obligación, de tal manera que por la sola llegada del plazo se entienda incumplida la obligación y se abran todos los remedios a disposición del acreedor, en especial, la resolución contractual cual es el medio de tutela más radical. Por lo tanto, se favorece con esto la conformidad del cumplimiento, antes que el ejercicio de las acciones y remedios del acreedor, otorgándole al deudor una posibilidad para subsanar el cumplimiento defectuoso ${ }^{50}$.

\section{La distinción entre plazo esencial y no esencial.}

Las dos dificultades apuntadas con anterioridad, nos hacen preguntarnos sobre el verdadero efecto del vencimiento del plazo. En un sistema de constitución en mora ex re cualquier vencimiento del plazo constituye un incumplimiento esencial de la obligación, aun cuando el cumplimiento de la obligación sea posible y todavía sea útil al acreedor. Esto produce distorsiones

\footnotetext{
${ }^{50}$ Para una visión comparatista de los instrumentos de derecho contractual uniforme, puede consultarse TOMÁs MARTínez, Gema, La tendencia europea a favorecer la conformidad contractual en el tiempo señalado para el cumplimiento ("Cure by debtor"). Especial atención al Borrador del Marco Común de referencia, en Bosch CaPdevilla, Esteve (director), Nuevas perspectivas del derecho contractual (Madrid, Civitas, 2012), pp. 591-606.
} 
a la hora de calificar, especialmente, el incumplimiento necesario para dar lugar a la resolución toda vez que se ha estimado que la resolución por incumplimiento procede en virtud de un incumplimiento calificado como esencial.

Así, la interpretación que se le ha dado al 1551 № 1 , y que hemos reproducido más atrás, implicaría calificar que cualquier incumplimiento en atención al plazo permitiría la resolución contractual. De esta suerte, cualquier vencimiento del plazo importaría que todos remedios se encontraran a disposición del acreedor, incluida la resolución. Esta idea pugna con la actual que sólo los incumplimientos esenciales permitirían el ejercicio de la facultad resolutoria ${ }^{51}$, compartida ya por la doctrina uniforme en Chile ${ }^{52}$. $\mathrm{Y}$ asimismo, cuando el incumplimiento no es esencial se activarían otros remedios contractuales distintos de la resolución, con mayor frecuencia la pretensión de cumplimiento y la indemnización de daños.

Frente a este régimen de construcción muy estricto, el de la constitución en mora automática del deudor, se genera la necesidad de abrir la distinción entre plazo esencial y no esencial. El primero produce el incumplimiento definitivo de la obligación y por tanto la activación de todos los medios de tutela del acreedor, en cambio, el segundo no. Es decir, para ser concordantes con la idea que no cualquier incumplimiento permite la resolución del contrato, debe analizarse el problema en concordancia con los efectos del plazo. Por ello, la distinción entre plazo esencial y no esencial es útil a tal configuración.

${ }^{51}$ Así, los Principios de Derecho Europeo de Contratos en su artículo 9:301 otorgan al acreedor la facultad resolutoria sólo en caso que el incumplimiento sea fundamental o esencial (artículo 8:103 PECL); y en el caso de retraso, cuando el acreedor haya otorgado un plazo de gracia o adicional al deudor (artículo 8:106), el vencimiento de dicho plazo, siempre que sea razonable, produce la resolución automática del contrato. Esta regla ya había sido adoptada por la Convención de las Naciones Unidas sobre los contratos de compraventa internacional de mercaderías, artículos 47 y 49, 1 b) respecto de comprador, y 63 y 64, 1 b), del vendedor. De manera similar, se redactó el artículo 7.1 .5 de los Principios UNIDROIT sobre contratos comercial internacionales.

${ }^{52}$ En este sentido, Vidal Olivares, Álvaro, El incumplimiento resolutorio en el Código Civil, en Pizarro Wilson, Carlos (coord.), Estudios de Derecho Civil IV (Santiago, LegalPublishing, 2009), passim; Vidal Olivares, Álvaro, La noción de incumplimiento esencial en el "Código Civil", en Revista de Derecho de la Pontificia Universidad Católica de Valparaiso, 32 (2009), passim; Mejías Alonzo, Claudia, El incumplimiento que faculta a resolver el contrato a la luz de las disposiciones del Código Civil, en DE la MAZA Gazmuri, Ínigo (coordinador) Cuadernos de análisis jurídico. Colección Derecho Privado VII. Incumplimiento contractual. Nuevas perspectivas (Santiago, Ediciones Universidad Diego Portales, 2011), p. 171. Sin embargo, la esencialidad o no del plazo, desde el punto de vista del incumplimiento suficiente para declarar la resolución, es analizada marginalmente por estos autores. En concreto, VIDAL, A., El incumplimiento, cit. (n. 52), p. 357 n. 34; VIDAL, A., cit. La noción, cit. (n. 52), pp. 242-243. 
Creemos que la construcción de un sistema que permita distinguir entre plazos esenciales y no esenciales es posible a partir del mismo artículo 1551 CC. 53

Se recordará que habíamos suscrito anteriormente, siguiendo la opinión de Claro, que el artículo $1551 \mathrm{~N}^{\circ} 1$ no consagraba un régimen de mora exre. Para encontrarnos frente a un caso de mora automática habría que pactar expresamente la esencialidad o fatalidad del plazo. Así, el vencimiento de un plazo pactado como esencial o fatal en el contrato implicará que el deudor se constituya en mora, pues tal ha sido la voluntad patente de las partes.

Pero bien, puede suceder que las partes no se hayan valido de expresiones tan claras para otorgarle al plazo este carácter. Es aquí en que cobra importancia el No 2 del artículo $1551 \mathrm{~N}^{\circ}$ 2: "Cuando la cosa no ha podido ser dada o ejecutada sino dentro de cierto espacio de tiempo, y el deudor lo ha dejado pasar sin darla o ejecutarla". La doctrina nacional ha estimado que esta norma estaría en consonancia con el plazo tácito, es decir, "el indispensable para cumplirlo" (artículo 1494 inciso $2^{\circ}$ ). Según la opinión tradicional, el numeral reproducido se aplicaría en todos aquellos casos de prestaciones a tiempo futuro en que no exista un plazo expreso. De esta suerte, la llegada del plazo tácito constituiría en mora al deudor.

Esta sería una de las aplicaciones de la norma ${ }^{54}$. Pero creemos que no es la única.

El N ${ }^{\circ} 2$ del artículo 1551 se coloca en el caso genérico en que una prestación no haya sido ejecutada dentro de cierto espacio de tiempo, y su tenor literal no reduce su aplicación a las obligaciones a plazo tácito, sobre todo teniendo en consideración que el Código ya había con anterioridad definido qué debe entenderse como un plazo de este carácter. Esto es relevante, pues

\footnotetext{
${ }^{53}$ En nuestro medio nacional, López Díaz, Patricia, El término esencial y su incidencia en la determinación de las acciones o remedios por incumplimiento contractual del acreedor a la luz del artículo 1489 del Código Civil chileno, en Revista Chilena de Derecho Privado, 19 (2013), p. 70, estima que es posible asumir la distinción entre plazo esencial y no esencial a partir de los intereses del acreedor involucrados en la relación contractual, más allá del tenor del artículo 1551 que analizaremos a continuación. Según esta autora, cabría descartar la aplicación del artículo 1551, dado que no reconocería una satisfacción del interés del acreedor. Incluso, termina afirmando que no se recoge expresamente la distinción en el Código (íbid, p. 74). Como se verá nuestra opinión si bien es conteste en el reconocimiento de la distinción entre plazo esencial y no esencial, es contraria a ella pues nosotros sí estimamos que hay base para reconocer en el artículo 1551 al vencimiento del plazo una función satisfactiva del interés del acreedor como pasará a explicarse. Y, más, la idea de plazo esencial se obtiene a partir del mismo artículo 1551, aunque el Código no ocupe esa expresión.

${ }^{54}$ Así lo expresa Peñailillo Arévalo, Daniel, Obligaciones (Santiago, Editorial Jurídica de Chile, 2003), p. 477.
} 
impone al juez la necesidad de determinar si la obligación debía forzosamente cumplirse dentro de ese plazo o no, calificación que debe realizar siempre el tribunal tratándose de plazos tácitos. Pero, como la norma es amplia, también permite la calificación satisfactoria del plazo cuando las partes no hayan pactado fatalidad expresa del mismo de conformidad con el numeral anterior. Así, sin establecer el Código de manera patente la distinción entre plazo esencial y no esencial, se recoge esta distinción en el artículo 1551 № 2 . A partir de él entonces, el deudor se constituye en mora automática en todos los casos en que según la naturaleza de la prestación, no pueda cumplirse la obligación después del plazo.

Es necesario hacer presente que para el Código, hay sí un tipo de plazo que es siempre esencial, cual es el establecido para el cumplimiento de obligaciones dinerarias, de conformidad al artículo 1559, que analizaremos con detención más adelante. En este tipo de obligaciones, el retraso sí se confunde con la mora del deudor. Esta confusión sí tiene una justificación especial, pues está en estricta relación con el cobro de ciertos perjuicios, los moratorios, que se reducen a interés sobre el capital.

Esta lectura que le hemos otorgado al artículo $1551 \mathrm{~N}^{\circ} 2$, incluso, le da mayor importancia al № 3 , que es considerado por los autores como la regla general ("En los demás casos [...]"55). Si nuestras apreciaciones son correctas, habría que conceder que el número 3 no solo se aplica al incumplimiento de obligaciones sin plazo expreso o tácito, sino para todas aquellas situaciones en que el incumplimiento en razón del tiempo no es esencial.

En conclusión, puede afirmarse que en el Código hay bases suficientes para establecer un sistema que permita la calificación de plazos en esenciales y no esenciales. Esta calificación, a falta de declaración expresa por los contratantes, le corresponderá al juez de conformidad con el artículo 1551 № 2 CC. Esta interpretación guarda mayor consistencia con el texto del Código, con sus antecedentes históricos, e incluso con el estado actual en materia de plazos en el derecho contractual uniforme.

Las dificultades dogmáticas que presenta la interpretación tradicional que se le ha dado al artículo 1551 CC. y que hemos propuesto solucionar permiten, a su vez, postular una restricción de los efectos de la constitución en mora del deudor, materia que será tratada en el siguiente capítulo.

${ }^{55}$ Meza Barros, R., cit. (n. 6), pp. 134-136; Ramos Pazos, R., cit. (n. 8), p. 282; Barcia Lehmann, R., cit. (n. 8), p. 106; Fueyo Laneri, F., cit. (n. 6), p. 450; Abeliuk Manasevich, R., cit. (n. 6), II, p. 1005. 


\section{LECTURA RESTRICTIVA}

\section{DE LOS EFECTOS DE LA CONSTITUCIÓN EN MORA DEL DEUDOR}

En los capítulos anteriores hemos descrito el estado actual de nuestra doctrina y jurisprudencia mayoritarias sobre los efectos de la constitución en mora del deudor según el Código Civil. Como se ha señalado (I), en doctrina nacional se ha postulado que el solo vencimiento de cualquier tipo de plazo, expreso o tácito, constituye en mora al deudor, y permitiría el ejercicio de todos los remedios contractuales. Es decir, la constitución en mora del deudor, bajo el estado actual, constituye en sí misma la lesión al crédito y no un mero estadio especial del incumplimiento. Esto se produce, principalmente, porque en nuestra doctrina y jurisprudencia mayoritarias se ha configurado que el vencimiento de todo plazo constituye en mora al deudor (II), lo que plantea dificultades a la hora de calificar la verdadera importancia de la mora al analizar su alcance respecto de la operatividad de los remedios, en especial, frente al cumplimiento imperfecto. Esto nos ha llevado a realizar una relectura del artículo 1551, entendiendo que en ella se recoge, implícitamente la distinción entre plazo esencial y no esencial. Sólo en los primeros se produce la constitución mora automática, que no es la regla general. Para estos efectos debe determinar el tribunal si el plazo ha sido pactado con este carácter, o bien, si por la naturaleza de la prestación, la obligación no puede cumplirse con retraso.

Bajo estos supuestos, es posible realizar una interpretación restrictiva de los efectos de la mora del deudor. Es restrictiva, porque la llegada del plazo no constituye per se al deudor en mora, sino en realidad es sólo un retardo jurídicamente calificado que permite, por una parte, el cobro sólo de los perjuicios moratorios, y por otra, la traslación de los riesgos en manos del deudor, cual es su función propia.

\section{La mora del deudor activa sólo la indemnización moratoria, no la} compensatoria.

Según se describió en el primer capítulo de este trabajo, la doctrina ha señalado que la mora del deudor es requisito de toda indemnización de perjuicios. La redacción en términos absolutos del artículo 1557: "Se debe la indemnización de perjuicios desde que el deudor se ha constituido en mora, o si la obligación es de no hacer, desde el momento de la contravención", ha llevado a la doctrina a afirmar que la mora es un requisito de toda indemnización, compensatoria y moratoria.

El problema está dado fundamentalmente para la indemnización compensatoria toda vez que hasta el momento no hay dudas que la indemnización de perjuicios moratoria requiere de la constitución en mora del deudor. 
La idea que se tratará de demostrar en este apartado es que a pesar de la amplitud de la redacción del artículo 1557, él se encuentra reducido únicamente a los perjuicios moratorios, no a los compensatorios, que no requieren de la constitución en mora del deudor para su generación.

Para abordar la cuestión, creemos que es conveniente circunscribir el problema desde la funcionalidad que debe asignársele a la institución en estudio.

La constitución en mora se exige para la indemnización de perjuicios porque de alguna manera se certifica que desde ese momento el incumplimiento le causa perjuicio al acreedor ${ }^{56}$. Es decir, con la interpelación del acreedor (en la regla general del $N^{\circ} 3$ del artículo 1551) se le hace saber al deudor que su retraso ya le está produciendo perjuicio. En los incumplimientos a plazo esencial, ello no sería necesario, pues la llegada del plazo esencial constituye de manera automática al deudor en mora.

Ahora, si no se reclaman perjuicios moratorios, sino sólo compensatorios $^{57}$, ¿qué función cumple la mora del deudor? Para estos efectos, nos da la impresión que es más pertinente analizar la cuestión desde el punto de vista contrario, es decir, desde la perspectiva de aquellos incumplimientos (definitivos) pero no en razón del plazo. Piénsese en un incumplimiento defectuoso que reviste las características de esencial. $\mathrm{O}$ bien en una falta de entrega total de la prestación, ¿qué función cumple la mora del deudor para la procedencia de estos perjuicios, cuando lo relevante no es el retraso sino las otras facetas del incumplimiento en razón del interés del acreedor? Recordemos que en Francia se ha discutido la cuestión desde antiguo y hasta la actualidad ${ }^{58}$.

Nos da la impresión que más allá de la llegada del plazo, lo importante

${ }^{56}$ Dítz-Picazo, G., cit. (n. 36), pp. 83-84.

${ }^{57}$ Sobre el particular, asumimos aquella posición que distingue entre la indemnización de perjuicios ("id quod interest") y el cumplimiento por equivalente ("aestimatio rei”). Es decir, cuando hablamos de indemnización compensatoria entendemos que ella no cubre el valor de la prestación incumplida, sino solo los demás daños distintos a ella, pero que no derivan del retraso (indemnización moratoria). En Chile son partidarios de esta opinión BARAONA GonzÁlez, J., Responsabilidad contractual, cit. (n. 33), pp. 159 ss.; Bustamante Salazar, Luis, Autonomia del equivalente pecuniario o su integración dentro de la indemnización de daños y perjuicios, en VARAS BRAUN, Juan Andrés - Turner Saelzer, Susan (coordinadores), Estudios de Derecho Civil (Santiago, LexisNexis, 2005), pp. 105-126; Corral Talciani, Hernán, La extensión del resarcimiento de los daños contractuales: las reglas de la causalidad y de la previsibilidad, en El mismo, Contratos y daños por incumplimiento (Santiago, Abeledo Perrot-Legal Publishing, 2010), pp. 141 ss; Peñailillo Arévalo, Daniel, Responsabilidad contractual objetiva, en Pizarro Wilson, Carlos, Estudios de Derecho Civil (Santiago, Legal Publishing, 2009), IV, pp. 334-338.

${ }^{58}$ Véase más arriba la n. 8. 
es la calificación del incumplimiento en cuanto tal y no la certificación que desde ese momento el incumplimiento le produce daños al acreedor. Incluso en los llamados incumplimientos definitivos, lo relevante no es que el deudor se constituya en mora sino que ya no hay pie para un cumplimiento posterior. En estos casos, el retraso es irrelevante, puesto que permite por su naturaleza, cumplimiento posterior ${ }^{59}$. Y en aquellos incumplimientos no definitivos, pero esenciales no en razón del plazo (como lo sería un cumplimiento oportuno pero esencialmente defectuoso), nuevamente el retraso no es relevante para la calificación del incumplimiento, sino su magnitud.

Por el contrario, cuando sólo se cobran perjuicios por el retraso, los moratorios, la constitución en mora acredita, ya por interpelación automática en los plazos esenciales, ya por interpelación ex persona para los supuestos cubiertos por el artículo 1551 № 3 , la titularidad y el momento a partir del cual se deben los perjuicios.

Somos conscientes que de alguna manera con esta interpretación se restringe la aplicación del artículo 1557 en que el legislador no distingue (por lo que no sería lícito distinguir al intérprete). Sin embargo, de la aplicación del artículo 1557 en su tenor literal se producen algunas inconsistencias.

En primer lugar, como hemos descrito con anterioridad, parte de la doctrina estima que los daños pueden calcularse desde el incumplimiento no moratorio, previo a la constitución en mora del deudor ${ }^{60}$. En segundo lugar, la misma doctrina ha recalcado que el supuesto de mora recíproca (artículo 1552) sólo sirve para la excusa de los perjuicios moratorios, no los compensatorios $^{61}$. De esta manera, a pesar de lo amplia de la expresión del artículo 1557, debe restringirse su interpretación al caso de los perjuicios moratorios de tal manera que se guarde una coherencia entre el texto y los efectos de la mora del deudor.

\section{En las obligaciones dinerarias todo plazo es fatal y constituye al deudor} en mora desde la llegada del plazo.

Hace excepción a lo que se viene describiendo el ámbito de las obligaciones dinerarias. Entendemos por estas las que el contenido obligacional es el de pagar una suma de dinero, obligación que nace en su origen de un contrato $^{62}$. Estas obligaciones fueron disciplinadas por nuestro legislador en

${ }^{59}$ Baraona González, J., cit. (n. 3), pp. 372 ss.

${ }^{60}$ Caprile Biermann, B., cit. (n. 29), p. 89.

${ }^{61}$ Ibíd., p. 89.

${ }^{62}$ Por tanto, se excluyen aquellas obligaciones de dinero derivadas de la inejecución de un contrato, como lo sería el cumplimiento por equivalencia, o bien, restituciones en valor; y las de fuente distinta a la contractual, especialmente las que derivan de la responsabilidad extracontractual. 
el artículo 1559 CC. Para los efectos de la inejecución de estas obligaciones, el legislador establece que al acreedor no necesita justificar perjuicios, basta con el hecho del retardo para que se de por establecida la indemnización de perjuicios "por la mora" si el interés del acreedor por el perjuicio se reduce al cobro de intereses por sobre el capital (artículo 1559 №2).

Aquí, el efecto de la mora es automática: basta con el hecho del retardo para que se generen los intereses moratorios, que es el perjuicio que la ley presume por el uso del capital ajeno. De esto se colige que en las obligaciones de dinero la llegada del plazo constituye inmediatamente en mora al deudor, no siendo necesaria una interpelación especial por el acreedor. La norma cobra real sentido en el sistema que intentamos configurar, pues se configura como una excepción al artículo 1551 № 1 . Se recordará que hemos postulado que en virtud del artículo $1551 \mathrm{~N}^{\circ} 1$ el pacto de un plazo no implica que el plazo deba ser considerado como esencial, pues se requiere que las partes establezcan la fatalidad del mismo, es decir, que la obligación no pueda cumplirse en tiempo posterior. Sin embargo, el legislador entiende que en las obligaciones de dinero, siempre podría el acreedor cumplir posteriormente (aún por el procedimiento del pago por consignación, establecido en los artículos 1600 inciso $2^{\circ}$ y 1605 inciso $2^{\circ}$ ). Por esta razón, si bien en principio el pacto de un plazo en una obligación dineraria podría en principio no aparejar fatalidad, la ley da por constituido al deudor en mora: "basta con el hecho del retardo", prescribe el Código.

En este tipo de obligaciones el único efecto que tiene el vencimiento del plazo es constituir en mora al deudor para el cálculo de los perjuicios moratorios que consistan en intereses por sobre el capital. Como se trata de una obligación de género, el riesgo en la prestación carece de utilidad.

Pero bien cabe preguntarse si el acreedor puede cobrar otros perjuicios distintos a los intereses, y luego, si ello es efectivo, verificar cuál es la función que cumple la mora del deudor en este supuesto.

Se ha señalado por alguna doctrina que tratándose de obligaciones de dinero sólo se pueden cobrar intereses por sobre el capital. Así, Abeliuk expresa tajantemente: "en las obligaciones de dinero no existe indemnización compensatoria, por la razón de que ésta es justamente la suma de dinero que equivale al cumplimiento íntegro de la obligación. Si una persona debe dinero y no lo paga, el acreedor lo ejecutará, embargará bienes suyos suficientes, los sacará a remate y se pagará con el producto de la subasta" ${ }^{63}$. De la opinión de Abeliuk, se desprende que el único remedio disponible para el acreedor es la ejecución forzada de en las obligaciones dinerarias (lo que sería lógico en un mutuo), pero no se coloca en el caso preciso de obligaciones

${ }^{63}$ Abeliuk Manasevich, R., cit. (n. 6), II, p. 1037. 
de dinero que nazcan a partir de un contrato bilateral en que el acreedor pueda solicitar la resolución del contrato por el incumplimiento de dicha obligación ${ }^{64}$. Este sería el caso, por ejemplo, de la compraventa por no pago del precio (artículo 1873).

Gatica, por su parte, explica con mayor detención lo que ocurriría en las obligaciones dinerarias: "Se trata de ser consecuente con la naturaleza de las obligaciones de dinero, que las hace diferentes, en lo tocante a su indemnización, a las demás clases de obligaciones; y de armonizar de forma equitativa los intereses contrapuestos de las partes, pero sometiéndolo, en cambio, a un régimen rígido de resarcimiento, que limita la responsabilidad del deudor" ${ }^{\text {"5 }}$. Debe observarse, en todo caso, que la opinión de Gatica se basa en la confusión entre la pretensión de cumplimiento y el "id quod interest" ya que entiende que por tratarse precisamente de una obligación de dinero, la prestación no puede transformarse en su equivalente pecuniario, justificando que por ello sólo se deben intereses moratorios por sobre el capital adeudado ${ }^{66}$. Gatica, asimismo, funda su opinión en la dificultad que tendría el cálculo de los daños por incumplimiento de obligaciones dinerarias, lo que fundamentaría la norma del artículo $1559^{67}$.

Una opinión parcialmente contraria es formulada por Fueyo. Este autor es partidario de abrir la puerta a los perjuicios compensatorios en caso de incumplimiento de obligaciones dinerarias, pero sólo por desvalorización monetaria ${ }^{68}$.

Más allá de lo que sostiene la doctrina, la historia de la Ley parece indicar otra cosa, en el sentido que es posible reclamar daños compensatorios distintos de los daños moratorios consistentes en intereses.

El artículo 11 del título $11^{\circ}$ del "Proyecto de 1842 ", contenía la norma que hoy es el artículo 1559 CC. Aunque su redacción era bastante similar a la actual, sin embargo carecía de algunas expresiones de las que goza la actual norma.

Así, el inciso primero artículo 11 del título $11^{\circ}$ del "Proyecto de 1842 " establecía lo siguiente: "Si la obligación es de pagar una cantidad de dinero,

${ }^{64}$ Mas, es posible encontrar una contradicción en el mismo Abeliuk ManaseVICH, R., cit. (n. 6), II, p. 1041, especialmente n. 1146, puesto que pocos párrafos más adelante reconoce que el acreedor puede cobrar otros perjuicios, en contra de las opiniones de Claro, Gatica y Barros Errázuriz. Esta es la opinión de Alessandri RodríGuez, A., cit. (n. 10), p. 104; y Rodríguez Grez, P., cit. (n. 13), p. 256.

${ }^{65}$ Gatica Pacheco, Sergio, cit. (n. 6), p. 273.

${ }^{66}$ Ibíd., p. 250. Sobre la distinción entre la "aestimatio rei" e "id quod interest" y su recepción en el derecho nacional, véase más arriba la n. 57.

${ }^{67}$ Gatica Pacheco, S., cit. (n. 6), pp. 272-273.

${ }^{68}$ Fueyo Laneri, F., cit. (n. 6), p. 473. 
la indemnización de esta está sujeta a las reglas siguientes". Puede observarse que el proyecto de 1842 no contenía la expresión "por la mora" que tiene la norma actual, agregada en el "Proyecto de 1853" (artículo 1738). También, la regla segunda del "Proyecto de 1842" decía: "El acreedor no tiene necesidad de justificar perjuicios; basta el hecho del retardo". Debe advertirse también que el proyecto carecía también de la expresión "cuando sólo cobra intereses", agregada en el "Proyecto de 1847" (artículo 102).

De la redacción del artículo 11 del título $11^{\circ}$ del "Proyecto de 1842 ", puede advertirse que la norma tenía pretensiones de generalidad frente al incumplimiento de obligaciones dinerarias. La no inclusión de las expresiones "por la mora" y "cuando sólo cobra intereses", implicaba en el proyecto que cada vez que el acreedor demandara el incumplimiento de una obligación dineraria sólo podría cobrar intereses como perjuicios. Es más, no debía en ningún caso probar el daño, puesto que la ley lo presumía (regla segunda).

Esto cambió parcialmente en el "Proyecto de 1847", toda vez que la ley sólo liberó de la prueba de los perjuicios sólo cuando el acreedor cobraba intereses, pero mantuvo la regla general por el inciso primero de la norma; es decir, para el cálculo de los perjuicios derivados de cualquier obligación de dinero incumplida, igualmente debía aplicarse la norma en comento.

Nuevamente, el ámbito de aplicación del artículo 1559 se modifica con la redacción definitiva del inciso primero y de la regla segunda a partir del "Proyecto de 1853", redacción que se mantuvo en el proyecto definitivo. La norma restringe la aplicación del precepto sólo cuando se cobran intereses por la mora, no cuando se cobran otros perjuicios distintos a los moratorios. Y sólo en este caso, además, la ley libera al acreedor de la prueba del perjuicio. La restricción del ámbito de aplicación del artículo responde a la intención del legislador de limitar el campo de aplicación de esta norma.

Esto nos lleva a pensar que para los demás casos de incumplimiento de obligaciones dinerarias cuando no se busca el resarcimiento moratorio no se aplica el artículo 1559; y, por consiguiente no se presume el daño a partir de dicha norma.

Si se lee en esta clave la norma en comento, podemos extraer algunas conclusiones. En primer lugar, la constitución en mora del deudor sólo tiene por objeto el cobro de perjuicios moratorios (intereses), no de otros daños que pueda sufrir el acreedor. Para estos otros perjuicios, lo relevante ya no es el retraso, es decir que la obligación pueda ser cumplida con tardanza, sino que producto del incumplimiento del deudor se le han producido otras consecuencias desfavorables que puedan ser indemnizadas. Por lo tanto, en segundo lugar, el hecho de la constitución en mora automática del deudor es completamente irrelevante. La mora que establece dicho artículo no lo libera de la prueba del otro perjuicio que quiera reclamar, sólo de los intereses que 
se calculan con ocasión del № 1 del artículo 1551 (y su complemento por la Ley 18.010). En tercer lugar, cobra ahora con mayor sentido la expresión del artículo 1873 "Si el comprador estuviere constituido en mora de pagar el precio en el lugar y tiempo dichos [...]". La norma se coloca en el caso en que el deudor (el comprador) ya se hubiera constituido en mora de cumplir. Y esta constitución en mora no se debe sino a la constitución en mora automática especial de esta norma, para el solo caso de demandar perjuicios moratorios consistentes en intereses por sobre el capital. Y, en cuarto lugar, la redacción de la norma da a entender que la mora del deudor no es necesaria para demandar la indemnización compensatoria consistente en daños distintos de los moratorios, lo que a su vez corrobora la interpretación que hemos postulado anteriormente.

\section{No es requisito de operatividad de otros medios de tutela.}

Más allá del efecto restrictivo que se le ha asignado a la mora del deudor en cuanto a su aplicación a la indemnización de perjuicios, es posible sostener que la mora del deudor no es requisito de operatividad ni de la pretensión de cumplimiento, de la resolución y de la excepción de incumplimiento contractual. Trataremos de los dos primeros medios de tutela conjuntamente, y en segundo lugar, por separado, de la "exceptio non adimpleti contractus".

a) Cumplimiento y resolución por inejecución. La constitución en mora del deudor no puede ser considerada como un requisito de operatividad de los remedios ni de cumplimiento ni de la resolución por incumplimiento.

En los últimos años, la doctrina se ha uniformado en entender que la constitución en mora no es requisito de la resolución. Estos esfuerzos se han abocado a este último medio de tutela más que a la pretensión de cumplimiento. Sin embargo, veremos que algunos de estos argumentos utilizados para la resolución pueden ser aplicables también al cumplimiento.

La razón fundamental de texto por la que la resolución por incumplimiento no requeriría de mora para su operatividad es que el artículo 1489 CC. no la exige expresamente, a diferencia de lo que ocurre con la indemnización de perjuicios (y eventualmente la "exceptio non adimpleti contractus", según el artículo 1552, que se analizará más adelante).

Sin embargo, otros argumentos, distintos a la mera literalidad del texto del artículo 1489, encuentran sustento en la distinción entre deuda y responsabilidad. A este respecto, Enrique Barros opina que sólo respecto de la responsabilidad en sentido estricto requiere de mora del deudor, toda vez que la responsabilidad supone un juicio de reproche al deudor incumplidor; reproche que supone la calificación del retraso para efectos indemnizatorios a 
través de la constitución en mora del deudor ${ }^{69}$. Por el contrario, los remedios que atienden a la deuda (y no a la responsabilidad), prescinden de este juicio de reproche que pudiere significar la mora debitoris.

El problema se presentaría por la intervención de un caso fortuito, que no produzca imposibilidad en el cumplimiento, pues si la hay la obligación se extingue (artículo 1670), y no hay lugar al ejercicio de remedio alguno. Ahora, en el marco de un contrato bilateral, cuando la imposibilidad sobrevenida absoluta afecta al cumplimiento de una especie o cuerpo cierto, de tal suerte que no hay remplazo de él, el riesgo se coloca en manos del acreedor (artículo 1550), por lo que el contrato no se extingue, y en ese preciso caso no puede el acreedor demandar los remedios pues el incumplimiento del deudor de la especie se encuentra excusado.

Para abordar la cuestión sobre el efecto del caso fortuito que no produce la imposibilidad, es necesario señalar que el Código prescribe que la mora producida por caso fortuito exime de la indemnización (artículo 1547). Luego, habrá que determinar qué sucede con el resto de los remedios contractuales.

En un sistema de mora ex re, como lo ha entendido parte de la doctrina, la respuesta pasaría por discutir si la mora en sí misma es un retardo culpable o no, y la influencia de la culpa en el ejercicio de los demás remedios distintos a la indemnización. El caso fortuito tornaría el incumplimiento inimputable (el retraso en nuestro caso), y si se estima que la culpa (o el incumplimiento culposo) es requisito de los demás remedios, ellos no se abrirían a favor del acreedor ${ }^{70}$. De esta manera, la irrupción de un caso fortuito no permitiría el ejercicio ni de la pretensión de cumplimiento ni de la resolución.

Pero, cuando el análisis parte de la base que el incumplimiento es un hecho objetivo carente de ribetes culpabilísticos, tal como lo ha propuesto parte de la doctrina más reciente y autorizada en nuestro país ${ }^{71}$, entonces se hace necesario determinar quién corre con el riesgo de dicho caso fortuito.

${ }^{69}$ Barros Bourie, E., Finalidad, cit. (n. 31), p. 412

${ }^{70}$ Peñailillo Arévalo, Daniel, Responsabilidad contractual objetiva, en PizARRo Wilson, Carlos (coordinador) Estudios de Derecho Civil (Santiago, LegalPublishing, 2009), IV, pp. 331 ss.

${ }^{71}$ Vidal Olivares, Álvaro, Cumplimiento e incumplimiento contractual en el Código Civil. Una perspectiva más realista, en Revista Chilena de Derecho, 34 (2007) 1, pp. 48 ss.; BARros Bourie, Enrique, El contrato y hecho que causa daño como antecedentes de la responsabilidad, en Pizarro Wilson, Carlos (coordinador), Estudios de Derecho Civil (Santiago, LegalPublishing, 2009), IV, p. 307; Pizarro Wilson, Carlos, Hacia un sistema de remedios al incumplimiento contractual, en GUZMán BRITO, Alejandro (editor), Estudios de Derecho Civil (Santiago, LexisNexis, 2008), III, pp. 398 ss. Esto se discute especialmente en materia de resolución. Véase: Clemente Meoro, Mario, La facultad de resolver los contratos por incumplimiento (Valencia, Tirant lo Blanch, 1998). 
Y las opciones son necesariamente dos: o el acreedor o el deudor. El problema entonces se reduce en determinar la aplicación de la regla de riesgos (que los coloca en manos del acreedor, artículo 1550 CC.), a los casos fortuitos que no producen imposibilidad. Entendemos que este es el problema toda vez que el legislador al distribuir los riesgos del caso fortuito en manos del acreedor, lo priva de la acción resolutoria cuando la imposibilidad es absoluta en el caso de destrucción del cuerpo cierto debido. Por lo tanto, hay que resolver la situación del caso no regulado: la imposibilidad fortuita sobrevenida que no produce la destrucción de una especie o cuerpo cierto. Tal sería, por ejemplo, la retención por la autoridad (fuerza mayor) de la especie debida y que impide la ejecución de la obligación dentro del plazo (incluso puede extenderse el ejemplo a las obligaciones de género, y a las de hacer).

$\mathrm{Si}$ se entiende que la mora es requisito de operatividad de los remedios del cumplimiento y de la resolución, en esta situación el acreedor no podría ejercer ninguno de ellos. El deudor no estaría constituido en mora (el incumplimiento, el retraso, sería inimputable), aún cuando el plazo sea esencial. Por tanto, el riesgo se seguiría colocando en manos del acreedor, y con ello manteniendo el mismo criterio criticado de la regla contenida en el artículo 1550.

Por el contrario, si se limita la aplicación de la regla de riesgos al solo caso contenido en el artículo 1550 (sólo a la pérdida de la especie o cuerpo cierto debida), entonces, puede llegarse a la conclusión que el acreedor, a pesar de la fuerza mayor, todavía gozaría de las acciones de cumplimiento y de resolución. Sólo que no podrá demandar la indemnización de perjuicios ya que no habría culpa. Esta conclusión guarda mejor sentido con la crítica que se le ha dado al artículo 1550, en el sentido de mantener la regla de riesgos en el deudor y no del acreedor (como el sentido literal del artículo establece). Asimismo, esta opción interpretativa es concordante con un concepto amplio y objetivo de incumplimiento. Como el caso fortuito no obsta a la calificación del incumplimiento, permite al acreedor solicitar la resolución del contrato, independiente de la culpa y de la mora del deudor. Y, por último, permite dimensionar de mejor manera los efectos propios de la mora en el plano de sus efectos. En esta situación la mora es irrelevante, puesto que basta la insatisfacción del interés del acreedor en atención al plazo para el ejercicio de los remedios contractuales. Ahora, como el deudor no se ha constituido en mora (artículo 1547), en todo caso no es responsable de los perjuicios.

b) La excepción de incumplimiento contractual. Probablemente, el problema más álgido desde el punto de vista interpretativo es el de la excepción de incumplimiento contractual. Como se explicó anteriormente, la doctrina ha deducido la exceptio del artículo 1552 que establece que la mora 
recíproca no da lugar a los perjuicios. De aquí se ha señalado que hay por lo menos bases para la construcción de la exceptio ${ }^{72}$.

A nuestro entender, la coherencia del sistema de remedios debe pasar por desligar la excepción de incumplimiento contractual del artículo 1552, incluso como base para su construcción ${ }^{73}$.

El centro del problema es el siguiente: $s i$ se parte de la base que la mora recíproca puede constituir el punto de partida para la exceptio, entonces habría que conceder que la mora es requisito de la pretensión de cumplimiento, lo que no es concordante con un sistema de remedios por incumplimiento que se incardinen en base al solo hecho del mismo. De esta manera, si se parte de la base que ciertos remedios atacan solo a la deuda y no a la responsabilidad, como lo son la pretensión de cumplimiento y la resolución (a diferencia de la indemnización de perjuicios), en estos la mora no puede servir de base para su construcción.

Por ello, creemos que es más conveniente fundar la excepción de contrato no cumplido en otras razones, como lo es, por ejemplo, la sola simultaneidad del cumplimiento ${ }^{74}$, desligada totalmente de la mora del deudor. Con ello se mantiene la mora en su función propia: una forma de retardo jurídicamente calificado, y no un requisito de operatividad de los remedios que atacan a la deuda.

Por las razones descritas con anterioridad, tampoco la mora no juega ningún papel en los casos de suspensión del cumplimiento distintos de los supuestos de incumplimientos recíprocos. Nos referimos, en especial a dos normas del Código Civil: el artículo 1826 inciso $4^{\circ}$ a propósito de la posibilidad del vendedor de suspender la entrega de la cosa cuando teme el incumplimiento del comprador por haber mermado su fortuna; y el artículo 2159 que autoriza al mandatario a desistir del encargo (obviamente, sin responsabilidad) cuando el mandante por su parte ha dejado de cumplir lo pactado. En estas dos situaciones no hay simultaneidad en el cumplimiento. La primera de las normas se coloca en el caso en que vendedor deba entregar la cosa antes del pago del precio ${ }^{75}$. En la segunda, se autoriza al mandatario a

${ }^{72}$ Mejías Alonzo, Claudia, La excepción, cit. (n. 29), pp. 402 ss.

${ }^{73}$ Como lo sostiene, por ejemplo, Mejías Alonzo, Claudia, La excepción, cit. (n. 29), pp. 405 ss.

${ }^{74}$ Como lo afirma la misma autora: Mejías Alonzo, Claudia, La excepción, cit. (n. 29), pp. 405 ss.

${ }^{75}$ Nos hemos preocupado del análisis de esta norma en Contardo González, Juan Ignacio, La resolución por anticipación o por incumplimiento previsible. Intento de construcción a partir de los artículos 1826 del Código Civily 147 del Código de Comercio, en Domínguez Hidalgo, Carmen - González Castillo, Joel - Barrientos Zamorano, Marcelo - Godenberg Serrano, Juan Luis (coordinadores.), Estudios 
renunciar sin ulterior responsabilidad cuando el mandante no ha cumplido su obligación de proveer al mandatario de lo necesario para la ejecución del mandato (artículo $2158 \mathrm{~N}^{\circ} 1$ ). Aquí nuevamente no hay simultaneidad pues el mandante debe cumplir primero que el mandatario ${ }^{76}$.

\section{La función principal: la traslación de riesgos a manos del deudor.}

Más allá de la situación especial de las obligaciones de dinero, en que la sola llegada del plazo constituye en mora al deudor para el cálculo de los intereses moratorios, los efectos de la mora deben quedar relegados a la traslación del riesgo de la cosa debida a manos del deudor cuando el deudor se ha constituido en mora.

Como se ha explicado con anterioridad, la constitución en mora del deudor produce un efecto perpetuador de la obligación (perpetuatio obligationis), que sólo es admisible cuando el deudor debe una especie o cuerpo cierto. Como no hay sustituto en el mercado de ella (la prestación) se vuelve imposible de ser entregada en naturaleza frente a su extinción sobrevenida fortuita. Por ello, en esta situación el deudor debe el precio y la indemnización de perjuicios (artículo 1672 inciso $1^{\circ}$ ). A menos, que el caso fortuito igualmente hubiese producido el perecimiento de la cosa en manos del acreedor, en cuyo caso el deudor debe sólo la indemnización moratoria (artículo 1672 inciso $2^{\circ}$ ).

A diferencia de lo que sucede antes de la constitución en mora en que se presume la culpa del deudor en la destrucción del cuerpo cierto debido (artículo 1671), al deudor sólo le queda la excusa por el "precio" cuando el caso fortuito igualmente hubiese destruido la cosa en manos del acreedor. Por lo tanto, hay un traspaso del riesgo cuando el deudor se constituye en mora. En los unilaterales, el riesgo se mantiene en manos del deudor ("res perit domino"). En los contratos bilaterales, esto es más patente, puesto que el riesgo de manos del acreedor (con todo lo criticada que es la regla): aquí propiamente hay traspaso del riesgo, que antes del cumplimiento de la obligación se encontraba en manos del acreedor, y por la constitución en mora se traslada al deudor.

De esta suerte, este efecto de la mora evita la liberación del deudor haciendo operante la máxima extensión de su responsabilidad por el incumpli-

de Derecho Civil (Santiago, Abeledo Perrot - LegalPublishing, 2013), VIII, pp. 273276.

${ }^{76}$ De lo contrario, el mandatario tendría que realizar el encargo con fondos propios; siempre que no se requiera de prestaciones específicas que sólo puedan ser cumplidas por el mandante, como lo sería la entrega de ciertos documentos que no estén a disposición del mandatario. Ello justifica entonces que pueda renunciar el mandatario. 
miento ${ }^{77}$. Por ello, más que una sanción es una forma especial de distribución de riesgos que establece el legislador que opera en ausencia de pacto expreso entre las partes. En efecto, podría distribuirse de manera diversa este riesgo ${ }^{78}$.

Por esta razón fundamental, el incumplimiento moratorio se constituye como un retardo jurídicamente calificado, y no como la propia lesión del crédito. Es un retardo jurídicamente calificado, pues el retardo por sí solo (no moroso) es una especie de incumplimiento que permite el ejercicio de los remedios contractuales, incluso la indemnización de daños. Pues bien, con ello se circunscribe el derecho de los remedios al solo hecho del incumplimiento, la mora queda relegada a dos consecuencias bien precisas: al cobro de intereses por sobre el capital en las obligaciones de dinero, y a la traslación de los riesgos en las obligaciones de especie o cuerpo cierto. En las obligaciones de género (no dineraria), la regla general hoy día en la práctica, ya el retraso produce consecuencias que no deben estar ligadas a una especial característica del incumplimiento: la mora producida por la inejecución de la obligación genérica entonces nada aporta al incumplimiento, pues el género no perece (artículo 1510). Con ello, en todos los casos, el acreedor en la economía actual se encuentra protegido por el elenco de remedios, de conformidad con el interés que tenga dependiendo del tipo de obligación contraída ${ }^{79}$.

\section{Conclusiones}

De la presente investigación podemos extraer las siguientes conclusiones:

$1^{\circ}$ La doctrina chilena ha configurado la mora del deudor como un requisito fundante de todo el sistema de responsabilidad contractual en sentido amplio: es requisito de los medios de tutela de la indemnización de perjuicios (compensatoria y moratoria), cumplimiento, resolución y excepción de contrato no cumplido. Además de esta función, se le reconocen dos adicionales: traslada los riesgos de la especie o cuerpo cierto debido al deudor, y hace responsable al deudor por el caso fortuito.

$2^{\circ}$ La base de esta configuración del sistema de responsabilidad contractual se debe a que se ha estimado que el artículo 1551 CC., establece la regla según la cual el vencimiento de cualquier plazo constituye al deudor en mora ("dies interpellat pro homine"), llamado también sistema de mora automática o ex $r$. De esta manera, cualquier incumplimiento en razón del plazo permitiría el ejercicio de los remedios contractuales. Esta idea de la mora del deudor permitiría sostener que la mora del deudor es la propia lesión del crédito.

\footnotetext{
${ }^{77}$ Díez-Picazo Gíménez, G., cit. (n. 36), p. 467.

${ }^{78}$ De Lara Morales, J. (n. 37), p. 402.

${ }^{79}$ Díez-Picazo y Ponce de León, L., El retardo, cit. (n. 15), pp. 403-404.
} 
$3^{\circ}$ Sin embargo, una lectura más detenida del artículo 1551 permite sostener que la constitución en mora automática sólo se presenta en aquellos casos en que se ha pactado la fatalidad del plazo (artículo $1551 \mathrm{~N}^{\circ} 1$ ), o bien que da la naturaleza de la obligación se desprenda que la prestación no admita cumplimiento posterior a su vencimiento, sea de plazo expreso o tácito (artículo 1551 № 2).

$4^{\circ}$ La configuración clásica de la mora del deudor, no concordante de la opción interpretativa propuesta en este trabajo, produce un conjunto de dificultades hermenéuticas. En primer lugar, la mora se erige como un requisito formal de activación de los remedios contractuales que no ofrece ninguna funcionalidad relevante a la institución en estudio. En segundo lugar, dicho sistema no sirve para analizar el régimen del incumplimiento oportuno pero defectuoso. Y, en tercer lugar, no permite la recepción de las categorías de plazo esencial y no esencial que permiten dimensionar la importancia del vencimiento del plazo para la calificación de los remedios disponibles para el acreedor, en especial, la resolución por incumplimiento.

$5^{\circ} \mathrm{Si}$ se parte de una base de un régimen constitución en mora no automática en todos los casos (sino sólo en los casos de plazo esencial), es posible sostener una lectura más restringida que permite solucionar los problemas evidenciados, y asimismo, más apegada al sentido literal del Código.

$6^{\circ}$ Por consiguiente, la mora del deudor constituye una forma de retardo jurídicamente calificado (y no la propia lesión del crédito), con dos efectos muy precisos, o restringidos frente a lo que se señala por la doctrina tradicional. Por una parte, permite el cobro de intereses por sobre el capital en las deudas de dinero, de tal suerte que cualquier llegada del plazo en este tipo de obligaciones constituye al deudor en mora; y por otra, traslada los riesgos de la prestación en manos del deudor, quien se hace responsable por el acaecimiento de una imposibilidad sobrevenida fortuita.

\section{BIBLIOGRAFÍA}

Abeliuk Manasevich, René, Las obligaciones (6a edición, Santiago, Legal Publishing, 2014).

Alessandri Rodríguez, Arturo, De la compraventay de la promesa de venta (Santiago, Editorial Jurídica de Chile, 2003).

Alessandri Rodríguez, Arturo, Teoria de las obligaciones (Versión taquigráfica de sus clases por Ramón Latorre) (Santiago, Zamorano y Caperán, 1939).

BARAONA GONZÁLEZ, Jorge, Algunas consideraciones sobre el retraso en el cumplimiento de las obligaciones: su configuración y eficacia, en PIZARRO WiLsON (coordinador), Carlos, Estudios de Derecho Civil (Santiago, LegalPublishing, 2008), IV.

BARAona GonzÁlez, Jorge, Responsabilidad contractual y factores de imputación de daños: apuntes para una relectura en clave objetiva, en Revista Chilena de Derecho, 24 (1997). 
Barcia Lehmann, Rodrigo, Lecciones de Derecho civil chileno (Santiago, Editorial Jurídica de Chile, 2008), III: "De la teoría de las obligaciones".

Barros Bourie, Enrique, El contrato y hecho que causa daño como antecedentes de la responsabilidad, en Pizarro Wilson, Carlos (coordinador), Estudios de Derecho Civil (Santiago, LegalPublishing, 2009), IV.

BARros Bourie, Enrique, Finalidad y alcance de las acciones y los remedios contractuales, en Guzmán Brito, Alejando (editor), Estudios de Derecho Civil (Santiago, LegalPublishing, 2008), III.

Barros Bourie, Enrique, Tratado de responsabilidad extracontractual (Santiago, Editorial Jurídica de Chile, 2008).

Barros Errázuriz, Alfredo, Curso de derecho civil (Santiago, Nascimento, 1932).

Bustamante Salazar, Luis, Autonomía del equivalente pecuniario o su integración dentro de la indemnización de daños y perjuicios, en VARAs Braun, Juan Andrés - Turner Saelzer, Susan (coordinadores), Estudios de Derecho Civil (Santiago, LexisNexis, 2005), [I].

CAPRILE BIERMAnN, Bruno, Algunos problemas ofrecidospor la excepción de contrato no cumplido y, en especial, el de su invocación para atajar la acción resolutoria en el caso de incumplimiento reciproco de los contratantes, en Revista de Derecho de la Pontificia Universidad Católica de Valparaíso, 39 (2012).

Claro Solar, Luis, Explicaciones de derecho civil chileno y comparado (Santiago, Editorial Jurídica de Chile, 2013), V, De las obligaciones, 2 [tomo XI de la primera edición].

Clemente Meoro, Mario, La facultad de resolver los contratos por incumplimiento (Valencia, Tirant lo Blanch, 1998).

Contardo González, Juan Ignacio, La resolución por anticipación o por incumplimiento previsible. Intento de construcción a partir de los artículos 1826 del Código Civil y 147 del Código de Comercio, en Domínguez Hidalgo, Carmen, González Castillo - Joel, Barrientos Zamorano, Marcelo - Godenberg Serrano, Juan Luis (coordonadores), Estudios de Derecho Civil (Santiago, Abeledo Perrot LegalPublishing, 2013), VIII.

Contardo GonzÁlez, Juan Ignacio, Procedencia de la indemnización por incumplimiento reciproco, en Departamento de Derecho Privado Universidad De Concepción (coordonador), Estudios de Derecho Civil (Santiago, Abeledo Perrot - LegalPublishing, 2010), V.

Corral TAlCiANi, Hernán, La extensión del resarcimiento de los daños contractuales: las reglas de la causalidad y de la previsibilidad, en EL MiSmo, Contratos y daños por incumplimiento (Santiago, Abeledo Perrot - LegalPublishing, 2010)

De Lara Morales, Julio Manrique, La mora del deudor en las obligaciones civiles de hacer (Madrid, Centro de Estudios Registrales, 2001).

Díez-Picazo Giménez, Gema, La mora y la responsabilidad contractual (Madrid, Civitas, 1996).

Díez-Picazo y Ponce de León, Luis, Fundamentos de derecho civil patrimonial (Navarra, Thomson - Civitas, 2008), II: "Las relaciones obligatorias".

Díez-Picazo y Ponce de León, Luis, El retardo, la mora y la resolución de los contratos sinalagmáticos, en Anuario de Derecho Civil, 22 (1969) 2.

Fueyo Laneri, Fernando, Cumplimiento e incumplimiento de las obligaciones (Santiago, Editorial Jurídica de Chile, 2004).

García Goyena, Florencio, Concordancias, motivos y comentarios del Código Civil español (Madrid, Imprenta de la Sociedad Tipográfico-Editorial, 1852). 
Gatica Pacheco, Sergio, Aspectos de la indemnización deperjuiciospor incumplimiento de contrato (Santiago, Editorial Jurídica de Chile, 1959).

López Díaz, Patricia, El término esencial y su incidencia en la determinación de las acciones o remedios por incumplimiento contractual del acreedor a la luz del artículo 1489 del Código Civil chileno, en Revista Chilena de Derecho Privado, 19 (2013).

Malaurie, Philippe - Aynès, Laurent - Stoffel-Munk, Philippe, Les obligations (4a edición, Paris, Defrénois, 2009).

Mejías Alonzo, Claudia, El incumplimiento contractualy sus modalidades, en GUZMÁN Brito, Alejandro (editor), Estudios de Derecho Civil (Santiago, LegalPublishing, 2008), III.

Mejías Alonzo, Claudia, El incumplimiento que faculta a resolver el contrato a la luz de las disposiciones del Código Civil, en DE LA MAZA GAZMuri, Íñigo (coordonador), Cuadernos de análisis jurídico. Colección Derecho Privado VII. Incumplimiento contractual. Nuevas perspectivas (Santiago, Ediciones Universidad Diego Portales, 2011).

Mejías Alonzo, Claudia, La excepción de contrato no cumplido y su consagración en el Código Civil chileno, en Revista Chilena de Derecho, 40 (2013) 2.

Meza Barros, Ramón, Manual de derecho civil. De las obligaciones (10 ${ }^{a}$ edición, Santiago, Editorial Jurídica de Chile, 2007).

Palau Ramírez, Felipe - Pastor i Vicent, Manel - Palau Sastre, Ana María Talens Visconti , Eduardo Enrique, Presupuesto y efectos de la mora en Palau Ramírez, Felipe - Viciano Pastor, Javier (editores), Tratado sobre la morosidad (Cizur Menor, Aranzadi, 2012).

Peñailillo Arévalo, Daniel, Obligaciones (Santiago, Editorial Jurídica de Chile, 2003).

Peñailillo Arévalo, Daniel, Responsabilidad contractual objetiva, en Pizarro Wilson, Carlos (coordinador), Estudios de Derecho Civil (Santiago, LegalPublishing, 2009), IV.

Pizarro Wilson, Carlos, Hacia un sistema de remedios al incumplimiento contractual, en Guzmán Brito, Alejandro (editor), Estudios de Derecho Civil (Santiago, LexisNexis, 2008), III.

Ramírez, Felipe - Corberá Martínez, José Miguel, La morosidad en los instrumentos internacionales, en Palau Ramírez, Felipe - Viciano Pastor, Javier (editores), Tratado sobre la morosidad (Cizur Menor, Aranzadi, 2012).

Ramos Pazos, René, De las obligaciones (3a edición, Santiago, LegalPublishing, 2008).

Rodríguez Grez, Pablo Responsabilidad contractual (Santiago, Editorial Jurídica de Chile, 2003).

TOMÁs MARTÍnEZ, Gema, La tendencia europea a favorecer la conformidad contractual en el tiempo señalado para el cumplimiento ("Cure by debtor"). Especial atención al Borrador del Marco Común de referencia, en Bosch Capdevilla, Esteve (director), Nuevas perspectivas del derecho contractual (Madrid, Civitas, 2012).

Vidal Olivares, Álvaro, Cumplimiento e incumplimiento contractual en el Código Civil. Una perspectiva más realista, en Revista Chilena de Derecho, 34 (2007) 1.

Vidal Olivares, Álvaro, El incumplimiento resolutorio en el Código Civil, en Pizarro Wilson, Carlos (coordinador), Estudios de Derecho Civil (Santiago, LegalPublishing, 2009), IV.

Vidal Olivares, Álvaro, La noción de incumplimiento esencial en el "Código Civil", en Revista de Derecho de la Pontificia Universidad Católica de Valparaíso, 32 (2009).

Vidal Olivares, Álvaro, La pretensión de cumplimiento especifico y su inserción en el 
sistema de remedios por incumplimiento en el Código Civil, en Corral Talciani, Hernán - Rodríguez Pinto, María Sara (editores), Estudios de Derecho Civil (Santiago, LexisNexis, 2007), II.

Vidal Olivares, Álvaro, La pretensión de cumplimiento especifico y la responsabilidad por incumplimiento. Un intento de sistematización en el Código Civil, en Pizarro Wilson, Carlos - Vidal Olivares, Álvaro, Incumplimiento contractual, resolución e indemnización de daños (Bogotá, Editorial Universidad del Rosario, 2010).

Zimmermann, Reinhard, The Law of Obligations (Oxford, Oxford University Press, 1996). 